\title{
Value of PET imaging for radiation therapy
}

\author{
Constantin Lapa ${ }^{1}$. Ursula Nestle ${ }^{2,3,4} \cdot$ Nathalie L. Albert ${ }^{5} \cdot$ Christian Baues $^{6} \cdot$ Ambros Beer $^{7}$. \\ Andreas Buck ${ }^{8}$. Volker Budach ${ }^{9}$. Rebecca Bütof ${ }^{10,11}$ • Stephanie E. Combs ${ }^{12,13,14}$. Thorsten Derlin ${ }^{15}$. \\ Matthias Eiber ${ }^{16}$. Wolfgang P. Fendler ${ }^{17}$. Christian Furth ${ }^{18}$. Cihan Gani ${ }^{19,20}$ - Eleni Gkika ${ }^{2}$. Anca-L. Grosu2,3 . \\ Christoph Henkenberens ${ }^{21}$ • Harun Ilhan ${ }^{5}$ Steffen Löck ${ }^{10,11}$. Simone Marnitz-Schulze ${ }^{6}$ - Matthias Miederer ${ }^{22}$. \\ Michael Mix ${ }^{23}$. Nils H. Nicolay ${ }^{2,3}$ - Maximilian Niyazij,12 . Christoph Pöttgen ${ }^{24}$ - Claus M. Rödel25,26 . \\ Imke Schatka ${ }^{18}$. Sarah M. Schwarzenboeck ${ }^{27}$. Andrei S. Todica ${ }^{5}$. Wolfgang Weber ${ }^{16} \cdot$ Simone Wegen $^{6}$. \\ Thomas Wiegel ${ }^{28}$. Constantinos Zamboglou ${ }^{2,3}$. Daniel Zips ${ }^{19,20}$ • Klaus Zöphel 11,29,30,31,32 • Sebastian Zschaeck ${ }^{33}$. \\ Daniela Thorwarth ${ }^{19,34}$. Esther G. C. Troost ${ }^{10,11,29,30,35}$ (D) Arbeitsgemeinschaft Nuklearmedizin und \\ Strahlentherapie der DEGRO und DGN
}

Received: 1 June 2021 / Accepted: 9 June 2021 / Published online: 14 July 2021

(C) The Author(s) 2021, corrected publication 2021

\begin{abstract}
This comprehensive review written by experts in their field gives an overview on the current status of incorporating positron emission tomography (PET) into radiation treatment planning. Moreover, it highlights ongoing studies for treatment individualisation and per-treatment tumour response monitoring for various primary tumours. Novel tracers and image analysis methods are discussed. The authors believe this contribution to be of crucial value for experts in the field as well as for policy makers deciding on the reimbursement of this powerful imaging modality.
\end{abstract}

Keywords PET $\cdot$ Radiation oncology $\cdot$ Functional imaging $\cdot$ Radiomics

\section{Introduction}

Positron emission tomography (PET) has found its way into primary disease staging of numerous solid tumours and of lymphomas. This has mainly been the contribution of $2-\left[{ }^{18} \mathrm{~F}\right]$ fluorodeoxyglucose-([18 $\left.\left.\mathrm{F}\right] \mathrm{FDG}\right)$, a glucose analogue which depicts the altered metabolism of malignant tumours as well as the physiological metabolism of organs and inflammatory processes. Functional PET with $\left[{ }^{18} \mathrm{~F}\right] \mathrm{FDG}$ as radiopharmaceutical (FDG-PET) combined with anatomical imaging modalities, such as computed tomography (CT) and magnetic resonance imaging (MRI), has also altered radiation treatment planning and response assessment, in particular in lung cancer, prostate cancer and lymphoma. More-

This article is co-published in the journals Strahlentherapie und Onkologie and Nuklearmedizin-NuclearMedicine Molecular Imaging and Therapy, https://doi.org/10.1007/s00066-02101812-2 or https://doi.org/10.1055/a-1525-7029.

Esther G. C. Troost, MD PhD

esther.troost@uniklinikum-dresden.de

Extended author information available on the last page of the article over, local radiation dose-escalation, termed dose-painting, based on increased metabolism has been applied both in theoretical treatment planning studies as well as in the context of prospective clinical trials. Finally, tracers depicting additional tumour characteristics beyond glucose metabolism have become available and their value is being assessed. For many years, the incremental value of a close interaction between radiation oncologists and nuclear medicine physicians has been highlighted by interdisciplinary studies in various tumour entities. Whereas this review is primarily aimed to provide a concise overview over the current value of PET in radiation oncology, it might also serve as a stimulus for future collaboration in both daily practice and scientific trials to further enhance patient care.

\section{Primary brain tumours}

Different from peripheral oncological diseases, which are predominantly imaged with FDG-PET, non-glucose tracers have shown clear superiority in the workup of tumour lesions in the brain. This is due to their high physiological glucose consumption, leading to a low tumour-to-back- 
ground contrast and sensitivity for $\left[{ }^{18} \mathrm{~F}\right] \mathrm{FDG}$, as well as to a high glucose uptake of inflammatory cells, which particularly hampers the evaluation of equivocal lesions after radiotherapy [1-3]. Therefore, amino acid tracers such as $\left[{ }^{18} \mathrm{~F}\right]$ fluoroethyltyrosine $\left(\left[{ }^{18} \mathrm{~F}\right] \mathrm{FET}\right), \quad\left[{ }^{11} \mathrm{C}\right]$ methionine $\left(\left[{ }^{11} \mathrm{C}\right] \mathrm{MET}\right),\left[{ }^{18} \mathrm{~F}\right] \mathrm{FDOPA}$ or $\left[{ }^{18} \mathrm{~F}\right]$ fluciclovine $\left(\left[{ }^{18} \mathrm{~F}\right] \mathrm{FACBC}\right)$ are recommended for the assessment of gliomas and brain metastases [4, 5], while radiolabelled ligands of the somatostatin receptor type 2 (SSR2; e.g. $\left[{ }^{68} \mathrm{Ga}\right.$ ]Ga-DOTATOC, $\left[{ }^{68} \mathrm{Ga}\right] \mathrm{Ga}$-DOTATATE, or $\left[{ }^{18} \mathrm{~F}\right]$ SIFATATE) are used for the imaging of meningiomas due to their overexpression of the SSR2 [6].

\section{Radiotherapy planning}

Conventional MRI of the brain is the gold standard to delineate tumour extent in primary brain tumours. But yet, due to their infiltrative growth, tumour margins are inadequately assessed by MRI alone and histological studies have proven that amino acid PET may be more sensitive to detect the true tumour extent [7-12]. Therefore, the PET/RANO report [4] proposed that delineation of the so-called "biological tumour volume" (BTV) using amino acid PET might more accurately disclose the true tumour volume and that biologically more active tumour regions may be amenable for dose escalation/selective boosting.

Several trials have shown the value of PET to reduce classical margins for delineation of the clinical target volume (CTV). For example, a recent study reported that a $1.5 \mathrm{~cm}$ margin on $\left[{ }^{18} \mathrm{~F}\right] \mathrm{FET}$-PET based BTV and MRbased gross tumour volume (GTV) yielded equivalent results according to recurrence patterns compared to classical $2 \mathrm{~cm}$ margins while significantly reducing dose exposure to healthy brain parenchyma [13-16].

Concerning the clinical benefit, a small prospective trial suggested that amino acid PET-based re-irradiation may lead to enhanced survival compared to radiotherapy planning based on conventional MRI alone [17]. Currently, a multicentre phase II trial (GLIAA, NOA-10, ARO2013/1) is testing the hypothesis that $\left[{ }^{18} \mathrm{~F}\right] \mathrm{FET}-\mathrm{PET}$-based re-irradiation will be superior to radiotherapy solely based on conventional MRI [18].

Also with regard to radiotherapy planning of meningiomas, the MRI-based morphologic GTV delineation may be insufficient to truly address the entire tumour volume. Particularly for the detection of an intra-osseous meningioma infiltration or for the tumour delineation at the skull base, PET using SSR-ligands has been shown to strongly complement anatomical information from MRI and CT [19-21].

Taken together, PET is a highly valuable tool to complement conventional imaging to improve the therapeutic ratio [22].

\section{Treatment response and radiation-induced changes}

In contrast to $\left[{ }^{18} \mathrm{~F}\right] \mathrm{FDG}$, which is not valuable for the response prediction to radiotherapy [23, 24], early $\left[{ }^{18} \mathrm{~F}\right] \mathrm{FET}$ or $\left[{ }^{11} \mathrm{C}\right] \mathrm{MET}$-PET changes are predictors for progressionfree survival (PFS) and overall survival (OS) [25-29].

After radiotherapy to primary brain tumours or radiosurgery to metastases [6], MRI, similarly to FDG-PET, does not offer reliable specificity to differentiate tumour progression from treatment effects such as pseudo-progression (early event) or radiation necrosis (delayed toxicity) [1-3, 22, 30-32]. Contrarily, amino acid PET studies report a high diagnostic accuracy, which can even be increased by the evaluation of tracer uptake kinetics, at least for $\left[{ }^{18} \mathrm{~F}\right] \mathrm{FET}$ [33-35].

\section{Head and neck squamous cell carcinomas (HNSCC)}

In recent years, significant improvements in radio(chemo)therapy of head and neck squamous cell carcinomas (HNSCC) have been achieved.

The impact of FDG-PET on target volume (TV) delineation and dose prescription has been studied extensively. FDG-PET improves primary tumour delineation, in particular in advanced stages. FDG-PET based TV is smaller than the volume derived by CT or MRI, and thus FDG-PET has a significant impact on the radiation dose distribution [36-40]. Compared to CT or MRI, FDG-PET demonstrates a higher level of concordance with local tumour extent as identified on histopathology [38]. Prospective studies were able to show that the use of FDG-PET leads to a higher degree of conformal radiation dose distribution and to a decreased rate of late side-effects, without compromising effects of the irradiation [41, 42]. Leclerc et al. [41] conducted a study in oropharyngeal tumours employing TV delineation based on FDG-PET, which led to decreased radiation doses to the parotid glands and oral cavity.

FDG-PET cannot reliably localize small superficial tumour deposits of the primary tumour or nodal micrometastases. This underlines the high relevance of clinical assessment in HNSCC as well as the necessity to further improve imaging modalities in the context of radiation treatment planning.

Tracers imaging tumour cell hypoxia in HNSCC, $\left[{ }^{18} \mathrm{~F}\right] \mathrm{FMISO},\left[{ }^{18} \mathrm{~F}\right] \mathrm{FAZA},\left[{ }^{18} \mathrm{~F}\right] \mathrm{HX} 4$, have been validated against immunohistochemical staining and been applied for patient selection during the course of radiochemotherapy (RCHT; [43-50]). Several prospective clinical trials have assessed the value of $\left[{ }^{18} \mathrm{~F}\right] \mathrm{FMISO}-\mathrm{PET}$ for patient stratification. A recently published prospective clinical phase II study suggests that radiation dose may be deescalated from 
$70 \mathrm{~Gy}$ to $30 \mathrm{~Gy}$ in oropharyngeal cancer patients with no hypoxia on $\left[{ }^{18} \mathrm{~F}\right] \mathrm{FMISO}-\mathrm{PET}$ prior to or with a re-oxygenating tumour during radiation treatment $[51]$. $\left[{ }^{18} \mathrm{~F}\right] \mathrm{FLT}$ PET, an imaging biomarker of tumour cell proliferation in HNSCC, also holds high prognostic value regarding locoregional control [52-54]. Even though, the tracer has not yet found its way into routine clinical practice, owing to its complex synthesis.

The Fibroblast Activation Protein (FAP), which is highly expressed on the fibroblasts of tumour stroma is a relatively new biological target which can be addressed with suitable FAP inhibitors (FAPI) that can be labelled with several radionuclides such as Ga-68 and F-18. Syed et al. [55] have shown that a high tumour-to-background-ratio of the FAPligand along with significant alteration of TV-delineation in HNSCC patients. The value of PET using ${ }^{18} \mathrm{~F}$-labelled FAPI is being evaluated for a variety of tumours in the context of a prospective register (NCT04571086). The value of this novel radiotracer PET for radiotherapy planning is to be assessed in prospective clinical studies with relevant oncological endpoints.

\section{Non-small cell lung cancer (NSCLC)}

FDG-PET/CT has been recognized as the key imaging method for staging of (non-)small cell lung cancer $((\mathrm{N}) \mathrm{SCLC})$ and for detection of disease recurrence. High sensitivities and specificities reported for the detection of distant metastases allow for accurate staging and treatment allocation, i.e., local therapy with curative intent or systemic therapy for palliation, and high imaging contrast enables delineation of the primary tumour and lymph nodes for radiation treatment planning for both tumour types [56-58].

According to the present state-of-the-art, an FDG-PET$\mathrm{CT}$ scan in radiation treatment position should indeed be performed within 3 weeks before start of irradiation, even before chemotherapy is administered [59]. This scan may also be acquired as 4D-PET/CT for motion management, such as for stereotactic body radiotherapy (SBRT). For definition of the GTV containing the primary tumour and metastatic lymph nodes, institutionally standardized visual contouring is the most widespread method and the value of FDG-PET/MRI subject to ongoing research [58, 60]. Recently, it has been confirmed in an international randomized multicentre-trial, that the CTVs (containing GTV and additional assumed microscopic spread) can safely be reduced when using FDG-PET for treatment planning in the context of primary RCHT of locally advanced NSCLC [58].

Serial PET scans, combined with CT or MRI, have been investigated in multimodality protocols during induction treatment before radiotherapy or during definitive
RCHT aiming at either acquiring prognostic information or defining individualized treatment adaptation [61-63]. Semi-quantitative metabolic FDG-PET parameters (i.e. maximum standardised uptake value $\left(\mathrm{SUV}_{\max }\right)$, metabolic tumour volume (MTV)) during RCHT have been observed to significantly correlate with overall and progression free survival, and/or local tumour control, even when reassessment is performed early (at 2 or 3 weeks after the start of radiotherapy) [64-70]. Newer approaches using radiomics and artificial intelligence are under investigation, but robust independent features, including 4D-PET imaging, were not of complementary prognostic or predictive value [59, 71, 72].

Beyond $\left[{ }^{18} \mathrm{~F}\right] \mathrm{FDG}$, other PET tracers reflecting tumour characteristics expressed by NSCLC have been investigated. Regions of tumour cell hypoxia, which could be imaged using $\left[{ }^{18} \mathrm{~F}\right] \mathrm{HX} 4,\left[{ }^{18} \mathrm{~F}\right] \mathrm{FMISO},\left[{ }^{18} \mathrm{~F}\right] \mathrm{FAZA}$ or $\left[{ }^{62} \mathrm{Cu}\right] \mathrm{Cu}-\mathrm{ATSM}$, were found to be smaller than $\left[{ }^{18} \mathrm{~F}\right] \mathrm{FDG}$ and to only (partially) overlap with the regions detected by FDG-PET [73]. Hypoxia markers were found to predict poor outcome in early and advanced stage NSCLC patients and might be helpful to guide dose escalation strategies [74, 75]. $\left[{ }^{18} \mathrm{~F}\right] \mathrm{FLT}-\mathrm{PET}$ representing tumour cell proliferation has been used to monitor treatment response during RCHT as well as during targeted therapy [76-78].

\section{Oesophageal cancer}

Current ESMO and NCCN guidelines recommend staging PET/CT using $\left[{ }^{18} \mathrm{~F}\right] \mathrm{FDG}$ to identify otherwise undetected distant metastases in patients suffering from oesophageal cancer (EC) [79, 80]. Specifically, FDG-PET should be carried out in patients who are candidates for oesophagectomy to detect unknown metastatic spread, which may prevent patients from undergoing futile surgery. With the exception of cases with limited stage disease (i.e., cT1/2 cN0 M0) for which primary resection is indicated, the remaining patients are candidates for combined treatment using RCHT with either neoadjuvant or definitive intent $[79,80]$. However, curatively intended high-dose radiotherapy to the thorax could be associated with significant cardiac and pulmonary toxicity. Thus, limiting excessive radiation exposure to healthy tissue is of great importance to current research. The status of PET-based radiotherapy is less clear in EC than in NSCLC, although patients with oesophageal squamous cell carcinoma share several adverse features with lung cancer patients, especially a high rate of cardiovascular comorbidities. In addition, surgical resection of EC is associated with perioperative mortality estimated as high as $10 \%$, without an improvement of OS when compared to definitive RCHT in two phase-III studies $[81,82]$. In contrast to this, survival among patients with potentially curable oesophageal or oe- 
sophagogastric-junction cancer was improved, when neoadjuvant RCHT was administered [83]. However, parameters, which may be used to predict response to neoadjuvant or definitive RCHT, are urgently warranted for an individually tailored treatment.

Currently, there is no gold standard for delineation of radiation target volumes in EC. Nevertheless, several publications have demonstrated that PET imaging may lead to improvement in the efficacy of radiotherapy of EC. A large Dutch delineation study showed that FDG-PET influenced the delineated volume in the majority of benchmark cases [84]. Additionally, results from a small prospective clinical trial suggest a significant benefit of additional PET imaging, with 6 out of 20 patients enrolled receiving subsequent modifications to their radiation treatment following FDG$\mathrm{PET} / \mathrm{CT}$ when compared to patients receiving conventional imaging [85]. A recently published delineation proposal of neoadjuvant target volumes in EC is also based on FDGPET imaging, optimally acquired in treatment position [86]. Furthermore, preliminary retrospective data suggest that inclusion of PET into treatment planning potentially improves survival compared to conventional imaging [87].

Besides contributing to improved biological tumour delineation, PET parameters are additionally associated with favourable outcomes in neoadjuvant and definitive treatment settings. This holds true for baseline PET-parameters but even more so for interim PET parameters [88-92]. Novel PET-parameters (e.g. standard uptake ratio, SUR) obtained at interim showed very encouraging results in the selection of optimal candidates for organ preservation [93]. Moreover, the use of FDG-PET/CT for restaging following neoadjuvant RCHT enables detection of distant interval metastases in up to $9 \%$ of cases [94, 95]. Recent clinical trials have also indicated that response assessment by PET during chemotherapy can be used to escalate local therapies in non-responders [96]. Collectively, a large metaanalysis found that restaging by FDG-PET/CT may considerably impact on treatment decision-making [94]. Nevertheless, the clinical benefit of FDG-PET/CT for assessing response to definitive radiochemotherapy or neoadjuvant treatment before surgery remains controversial. Following German national guidelines, interim PET imaging is not routinely recommended [97]. Therefore, the further validation of the role and promising PET parameters with an emphasis on objective quantitative parameters for response assessment through prospective, multicentre studies is of utmost importance to further optimize personalized treatment approaches.

\section{Rectal cancer}

\section{PET in primary staging}

Regarding primary tumour staging, MRI is the gold standard and established in all international guidelines. MRI allows a reliable assessment of infiltration depth, mesorectal fascia involvement or infiltration of adjacent organs owing to its excellent soft tissue contrast [98]. In this aspect, MRI is superior to FDG-PET/CT imaging. Regarding nodal status, no single modality achieves high accuracy for the prediction of lymph node involvement. For MRI staging, morphological features such as shape and signal intensity outperform size [99]. Thus far, no study has compared MRI with FDG-PET/CT regarding nodal status. There are a number of studies showing partial superiority of FDGPET imaging compared with conventional imaging. Kwak et al. [100] analysed 473 patients and found a sensitivity of $66 \%$ with a specificity of $60 \%$ using FDG-PET/CT. On CT, there was a significantly lower specificity of $29 \%$ with slightly higher sensitivity of $87 \%$. Overall, this resulted in a non-significantly different accuracy of $63 \%$ for FDGPET/CT and of 59\% for CT only [100]. No difference was documented for the detection rate of lymph node metastases. In another study, univariate and multivariate analysis demonstrated that quantitative parameters obtained from FDG-PET (MTV, SUV max $_{\text {) }}$ were independent predictors of the presence of lymph node metastases [101].

\section{PET for radiation planning}

The 'classic' target volume for locally advanced rectal cancer in the neoadjuvant setting includes the entire mesorectum in addition to the primary tumour, and thus also the rectum up to the level of the promontory. Pelvic lymphatics are included depending on the clinical scenario (S3 guideline Colorectal Carcinoma [102]). Usually, the entire target volume receives a uniform dose, such that a highly precise delineation of the primary tumour is not of clinical relevance. However, clinical trials are currently investigating whether dose escalation to the primary tumour can lead to an increase in complete remission rates and thus allow for an organ-preserving approach in a larger number of patients [103]. Here, a precise definition of the primary tumour is relevant to apply the highest possible dose to the primary tumour while sufficiently sparing normal tissue. Several studies have compared MRI and FDG-PET-based primary tumour definition. The FDG-PET-based primary tumour delineation consistently resulted in a smaller tumour volume compared to the MRI-based definition [104, 105]. However, it should be taken into account that, as described above, an excellent correlation with the actual tumour extent has been established for MRI. For FDG-PET-based 
primary tumour definition, these data are currently lacking. Furthermore, it should be considered that the rectum shows an extremely variable anatomy and a tumour volume generated based on "offline" image data requires a large safety margin to be irradiated. Overall, the utility of FDG-PET/CT in target volume definition in rectal cancer seems limited.

\section{PET for response assessment}

The prediction of a clinical complete remission is one of the major challenges in establishing organ preservation strategies, as neither endoscopic assessment nor MRI after therapy have shown reliable sensitivity to date [106]. A promising approach is to incorporate early changes in functional, quantifiable imaging data, such as FDG-PET/CT [107]. In a prospective study comparing quantitative imaging methods with molecular markers in terms of predictive power for complete remission, imaging methods including FDGPET/CT were shown to have the highest sensitivity of approximately $80 \%$ [108].

\section{Anal cancer}

The standard of care of non-metastatic anal cancer is definitive, organ-preserving concurrent RCHT [109, 110]. Due to usually high FDG-avidity of the primary tumour, locoregional lymph node and distant metastases, FDG-PET/CT may provide useful diagnostic information for RCHT planning [111-116]. Furthermore, PET-derived metabolic biomarkers including pre-treatment $\mathrm{SUV}_{\max }$ and MTV have shown prognostic significance in terms of OS, PFS and event-free survival (EFS) [111, 117, 118].

FDG-PET/CT can be helpful in identifying the primary tumour, but both the spatial resolution of PET and physiologic anal uptake limit accurate T-staging [119, 120]. Thus, MRI and transanal endoscopic ultrasound remain the clinical standard for T-staging [121-123]. Although data on the use of FDG-PET/MRI are limited, recent data indicate that PET/MR provides a more precise assessment of the local extent of rectal cancers in evaluating cancer length, nodal (N) status, and external sphincter involvement [124]. There is good agreement between FDG-PET- and MRI-based GTVs [125]. Accurate N-staging is crucial for dose prescription and target volume delineation concerning (elective) lymph node irradiation by consensus contouring guidelines and definition of boost volumes (simultaneously integrated or sequential) for involved lymph node disease [126, 127]. A particular strength of FDG-PET/CT is the additional detection of small lymph node metastases in unsuspected pelvic and inguinal lymph nodes, and the detection of occult distant metastases.
Several studies focused on the impact of FDG-PET/CT for radiation treatment planning and target volume definition. Two meta-analyses focused on disease staging with a particular focus on radiation treatment planning: FDGPET/CT led to upstaging in 5-38\%, and to downstaging in $8-27 \%$ of patients; the identification of lymph node metastases lead to treatment plan adaptions in $12.5-59 \%$ of patients [120, 128]. Furthermore, recently published data reported that up to $20-26 \%$ of FDG-PET positive lymph nodes were located outside the target volume of common guidelines for elective lymph node irradiation and would have been missed without the FDG-PET/CT-derived information [129].

Additionally, FDG-PET/CT_performed 12 weeks after completion of RCHT - may be useful to identify patients with insufficient metabolic response of the primary tumour predicting the need for early salvage therapy [130, 131]. A metabolic partial response was predictive for a significantly decreased 2-year PFS compared with metabolic complete response $(22-71 \%$ versus $95 \%$ [131, 132]). However, as reported in the meta-analysis of Jones et al. [128], FDGPET/CT performed too early during follow-up occasionally prompted unnecessary resection. Therefore, and since according to current guidelines the final response of anal cancer should be assessed as late as 26 weeks after RCHT, the timing of an FDG-PET scan during follow up should be late and any consequences should be drawn with caution.

\section{Cervical cancer}

External beam RCHT followed by 3D-planned MRI-based brachytherapy maximizes tumour doses for excellent local control rates and is thus the standard of care [133]. Even though, lymph node metastases are the most important prognostic factor in cervical cancer patients, which is not considered in the current FIGO classification. This results in under- or overtreatment of patients and an unacceptably high rate of postoperative RCHT [133, 134]. CT and MRI have demonstrated disappointingly low accuracy rates in primary lymph node staging. Consequently, in some countries FDG-PET/CT has been increasingly used to overcome the limitations in accurate lymph node staging. Since FDGPET/CT suffers from a high rate of false negative readings of up to $20 \%$, FDG-PET/CT cannot replace laparoscopic staging [135, 136]. Thus, laparoscopic staging is widely applied leading to upstaging in $>30 \%$ of locally advanced cervical cancer patients and allowing for treatment triage (radical hysterectomy versus definitive RCHT). Recently, the randomized trial Uterus-11 has shown that laparoscopic staging did not only avoid under- or overtreatment, but had an impact on disease-free survival and cancer-specific survival, respectively, without increased toxicity rates [137]. 
Laparoscopic staging therefore remains the gold standard for FIGO stage IIB and > IIB patients [137-139].

The implications of undertreating patients with false negative para-aortic disease is disastrous, given the fact that the survival rate for patients with histologically positive para-aortic lymph nodes treated with extended-field radiation therapy is as high as 50\% [140]. A prospective trial evaluated the use of laparoscopic staging after (false) negative FDG-PET/CT and showed significantly superior oncological outcomes for patients with lymph node metastases $<5 \mathrm{~mm}$ vs. $>5 \mathrm{~mm}$ after surgical staging and RCHT [141]. The shortcoming of the above mentioned Uterus-11 trial [137] is that FDG-PET/CT was not used in that study. The idea of combining the validation of FDGPET/CT and laparoscopic staging has been discussed by the LilACS study group. The study aimed at randomizing patients with FDG-PET/CT positive pelvic, but negative para-aortic lymph nodes to either laparoscopic lymph node dissection or pelvic RCHT [142]. Unfortunately, the trial was not able to recruit a sufficient number of patients and was subsequently closed. This approach should be the aim of a future multicentre trial.

FDG-PET/CT-based therapy response assessment allows for a reliable prediction of overall survival in patients with locally advanced cervical cancer treated with concomitant RCHT [143]. This should be used within clinical trials to tailor adjuvant treatment, e.g. maintenance treatment with immunotherapy in case of persistent FDG uptake. In the setting of neoadjuvant RCHT, data showed that early changes in metabolic FDG-PET parameters might allow for differentiation of histopathological response of the primary tumour [144]. However, negative results of two randomized trials have now questioned the role of neoadjuvant chemotherapy at all [145, 146]. FDG-PET/CT has a high sensitivity and specificity in the detection of distant metastases, which may lead to a change of the treatment intent (curative versus palliative [147]). However, FDG-PET uptake depends on the histological subtype being highest in squamous cell carcinoma, whereas e.g. mucinous adenocarcinoma often show only faint $\left[{ }^{18} \mathrm{~F}\right] \mathrm{FDG}$ uptake resulting in a limited sensitivity in these subtypes [148].

Regarding restaging of cervical cancer, a recently published meta-analysis showed a pooled sensitivity of 0.97 (0.95-0.99) for FDG-PET/CT. 57\% of the therapeutic approaches were modified due to the results of FDG-PET/CT [149]. At present, according to national guidelines, in the setting of recurrent cervical cancer, FDG-PET/CT might be reserved for individual patient cases for tailored treatment [150]. In the follow-up, FDG-PET/CT remains a helpful tool after RCHT or radical hysterectomy, even in patients with increasing tumour markers and negative MRI findings.

In the future, the use of hybrid PET/MRI protocols could contribute to improve imaging of cervical cancer patients, and the use of alternative PET radiopharmaceuticals, e.g., $\left[{ }^{68} \mathrm{Ga}\right] \mathrm{Ga}-\mathrm{FAPI}$ is under investigation [151].

\section{Prostate cancer}

\section{PET in primary staging}

Accurate detection of intra- and extraprostatic tumour foci by imaging is of high clinical relevance for radiation treatment planning in patients with primary and recurrent prostate cancer. A large of number studies performed during the last 5 years has shown that PET imaging with radiolabelled small molecule inhibitors of the glutamate carboxypeptidase PSMA (prostate specific membrane antigen) allows for more sensitive and specific detection of prostate cancer lesions than other imaging techniques. Several radiolabelled PSMA inhibitors have been developed but most of the clinical so far has been obtained with the ligand $\left[{ }^{68} \mathrm{Ga}\right] \mathrm{Ga}$-PSMA-11 [152-154]. This radiotracer has recently been approved by the FDA for imaging of primary and recurrent prostate cancer. Several ${ }^{18} \mathrm{~F}$-labelled PSMA inhibitors are being investigated in prospective clinical trials; these tracers can be produced in larger batch sizes and have better physical properties for PET imaging. Furthermore, some of them show less urinary excretion, which facilitates detection of primary tumours and local recurrences. The diagnostic performance of these ${ }^{18} \mathrm{~F}$-labelled tracers is overall probably similar or superior to $\left[{ }^{68} \mathrm{Ga}\right] \mathrm{Ga}-$ PSMA-11, but head-to-head comparisons are so far limited [152-155]. Therefore, the results of these various agents are summarized under the name 'PSMA-PET/CT' in the following text.

In the primary setting, PSMA-PET/CT imaging can be applied for initial staging in patients with high-risk profiles [156]. A prospective phase III study (proPSMA) showed that the application of PSMA-PET/CT has relevant impact on patient management since the accuracy for lymph node and bone metastases is higher as compared to conventional imaging [157]. In particular the performance of PSMAPET/CT often leads to changes in TNM-staging with subsequent alterations in radiation treatment planning. Several retrospective analyses have also addressed this issue. Dewes et al. [158] reported on a change in TNM stage in 8 of 15 patients or modifications of CTVs and changes in prescribed dose in 5 and 12 patients, respectively. In another retrospective analysis, PSMA-PET/CT was shown to have a major impact on final radiotherapy planning in approximately one-third of the patients, especially when no elective radiation to the pelvic lymphatic drainage system was initially planned [159]. Recently, another phase III trial has been started which randomizes patients with unfavourable, intermediate, and high risk profiles to a group 
with and a group without PSMA-PET for definitive radiotherapy planning (NCT04457245).

In addition, in prostate cancer a clear dose-response relationship could be described. The prospective multicentre phase III study 'FLAME' demonstrated that dose escalation to intraprostatic tumour lesions defined by MRI imaging resulted in a significant improvement in recurrencefree survival [160]. However, it can be assumed that the intraprostatic tumour mass determined on the basis of PSMAPET information can be contoured with a higher sensitivity [161-164]. Zamboglou et al. [165] reported on the feasibility of dose escalation to intraprostatic lesions defined by $\left[{ }^{68} \mathrm{Ga}\right.$ ]Ga-PSMA to $95 \mathrm{~Gy}$ in 10 patients. Thus, a multicentre phase II study from Germany is currently investigating focal dose escalation to intraprostatic tumour volumes defined by combined PSMA-PET/CT and MRI imaging (HypoFocal; DRKS00017570). Of note, PET/CT imaging for prostate cancer in Germany almost is now exclusively performed with PSMA-ligands and Choline-derivatives have been completely replaced. Phase III studies are already underway to investigate whether the use of PET/CT imaging and the associated individualization of the therapeutic approach leads to the expected improvement in oncological outcome.

\section{Salvage radiotherapy in recurrent prostate cancer}

Before the introduction of PSMA-PET/CT, usually no extensive imaging workup was indicated in low-level biochemical recurrence (increasing PSA out of the undetectable range) after radical prostatectomy (RP) or a persisting PSA after RP before salvage radiotherapy (SRT, start of RT at a PSA-level $<0.5 \mathrm{ng} / \mathrm{ml}$ ) due to the known limited accuracy of conventional staging with CT and bone scintigraphy [166-168]. An exception is MRI with dynamic contrast enhanced MRI (DCE-MRI) which shows excellent results for identifying small areas of local recurrence, however has not been widely used in clinical routine up to now [169, 170]. The situation has changed substantially with PSMA-specific PET radiotracers, which show superior sensitivity and specificity for detecting recurrent prostate cancer compared with conventional imaging and also compared to other radiotracers such as choline-based substances or fluciclovine [171-173]. PSMA-PET/CT appears to be particularly effective at low PSA levels after radical prostatectomy below $0.5 \mathrm{ng} / \mathrm{ml}$ when $\mathrm{SRT}$ to the prostate bed would typically be initiated and may even detect recurrent disease in $33-42 \%$ of patients at PSA levels $<0.2 \mathrm{ng} / \mathrm{mL}[174,175]$. Most studies used ${ }^{68} \mathrm{Ga}-$ labelled PSMA compounds, however, these are more and more replaced by ${ }^{18} \mathrm{~F}$-labelled PSMA tracers, as these can be produced in higher quantities and also mostly have less renal excretion, thus showing superior image quality adja- cent to the bladder for identification of local recurrences [176]. Recent reports also suggest that PET/MRI might be advantageous in this respect and superior to PET/CT for detection of local recurrences [177, 178].

Through improved characterization of recurrent prostate cancer, PSMA-targeted PET/CT has shown significant impact on management decisions, such as by identifying patients with recurrence confined to the prostate or pelvic nodes $[179,180]$. At a PSA value of less than $0.5 \mathrm{ng} / \mathrm{mL}$, PSMA-PET/CT detects lymph node metastases in approximately $20 \%$ of patients [181]. Thus, PSMA-PET/CT in the setting of biochemical recurrence with low PSA values changes patient management in nearly $50 \%$ of the patients according to a review of 45 studies evaluating the use of PSMA-PET/CT in the setting of biochemical recurrence [181].

Of special relevance in this respect is the identification of distant metastases, mostly to the bone, which can even occur in the group with low-level biochemical recurrence $(10 \%$ at a PSA level $<0.5 \mathrm{ng} / \mathrm{mL})$ and in case of oligometastatic disease might be irradiated as well or in more extensive metastatic disease might change the original treatment concept completely [182]. Moreover, adaption of the radiation target volume was noted such as extension of the field to include suspicious lymph nodes or in case of atypically localized recurrences at the border of the standard target volume [183-185]. The success of PSMA-PET/CT has also led to the inclusion in the German S3 guideline for diagnosis and treatment of prostate cancer as an option for imaging in case of low-level biochemical recurrence after RP before SRT [186]. However, it has to be stressed that in case of a negative PSMA-PET result, SRT shall not be delayed as 'blind' prostate SRT remains an effective treatment. Moreover, while one expects PSMA-PET guided SRT with potentially also a dose-escalated simultaneous integrated boost directed to the PSMA-positive local recurrence to have a positive impact on the course of the disease, e.g., improved success rates concerning PSA-response, the ultimate clinical value and influence on progression survival or even overall survival is not yet known. This will be evaluated in ongoing prospective randomized studies (Clinicaltrials.gov NCT01666808, NCT03762759, NCT03525288) including a phase III study (NCT03582774) in the setting of post-RP biochemical failure, which compare the current standard of care (salvage RT to prostatic fossa) with PSMA/ fluciclovine PET-CT-guided SRT.

\section{Malignant lymphoma}

FDG-PET has significantly changed the treatment of malignant lymphomas (ML) in recent years. This is especially true for radiation oncology. 


\section{PET in the context of staging}

In the case of exclusive radiation, e.g. in follicular lymphoma (FL) or lymphocyte-predominant Hodgkin's lymphoma (HL), FDG-PET plays a crucial role. Staging must be performed as accurately as possible to ensure, first, that early stage is present and, second, that all affected lymph nodes are included in the target volume. The use of FDG-PET has led to systematic up-staging in early stages [187-189], at the same time showing improved PFS for early stage FL [190, 191]. Also in the context of combined treatment with chemotherapy followed by consolidative radiotherapy according to the involved site (ISRT) definition, PET helps to define a correct and adequate target volume size [192].

\section{The benefits of PET in the context of target volume definition}

FDG-PET has played a critical role in early stage ML radiation treatment planning. CT-morphologically normal lymph nodes can be included in the target volume when positive on FDG-PET [193-196]. This can reduce recurrences due to geographical misses [194, 197, 198]. Also, in advanced stages, extranodal involvement can be better detected, implementing FDG-PET in the ILROG guidelines for treatment of ML [199-201]. Whenever FDG-PET is performed as part of staging, the patient positioning is usually not identical to that for radiation therapy. Thus, FDG-PET and the planning CT scans need to be fused for the treatment planning purposes. Since spatial discrepancy in the area of affected lymphomas may arise, the ISRT definition is applied, which takes into account a greater uncertainty in positioning [200]. Whenever the FDG-PET scan is performed in the setting of a treatment planning PET/CT, the imprecision of the CTV definition is very small and consequently, the involved node (INRT) definition can be used [202].

\section{The utility of PET for therapy stratification in the combined modality setting}

Based on the Lugano criteria, PET is used as part of the re-staging of ML [203]. Assessment is based on a 5-point scale, the Deauville Score (DS), which evaluates lymphoma activity in comparison with the mediastinum and liver. In various studies, two main treatment stratification approaches have been and are being pursued; (1) whether a negative progression PET can de-escalate therapy, e.g., by omitting radiotherapy or reducing chemotherapy, and (2), whether therapy escalation can be performed by a positive interim PET. Therefore, in particular a DS3 score is sometimes evaluated differently in escalation and deescalation studies [204, 205]. The statement of a metabolic complete remission after chemotherapy has prognostically favourable significance for patients with both $\mathrm{HL}$ and diffuse large-cell B-NHL (DLBCL). However, local recurrences still occur in some cases when radiotherapy has not been given because of negative PET after chemotherapy. This is particularly confirmed in a number of studies for early stages [204-208]. The data on FDG-PET-guided radiotherapy in $\mathrm{HL}$ is now secure for intermediate and advanced stages. In DLBCL, the results of the pivotal trials are not yet conclusive. However, FDG-PET-guided radiotherapy indication in the advanced stages seems to be established here as well.

\section{Future prospects}

\section{$\mathrm{PET} / \mathrm{CT}, \mathrm{PET} / \mathrm{MRI}$ and radiomics in radiotherapy planning}

Multimodal FDG-PET/CT and PET/MRI data have been shown by various studies to improve RT planning in different aspects, such as better patient selection and precision in target delineation [58, 193, 209-215]. Inclusion of $\mathrm{PET} / \mathrm{CT}$ or PET/MRI data into radiation dose planning requires dedicated acquisition protocols [216-220] to ensure reproducible manual or automatic contouring of tumour regions [210, 221-223].

Furthermore, PET/CT and PET/MRI data can be used for automated high-throughput radiomics analyses [224, 225]. In such studies, standardised quantitative image characteristics are extracted to develop models that support the diagnosis of tumour diseases, the prediction of therapy adaptation, or the prognosis of therapy response, using modern methods of artificial intelligence [226-231]. For applicability in clinical practice, efforts on a standardised and reproducible radiomics workflow are decisive [232-237]. To further improve reliability, imaging characteristics may be combined with molecular and clinical information in a multi-omics approach [238].

\section{New PET tracers}

While amino-acid-based PET tracers, somatostatin receptor specific PET tracers and PSMA ligands are already used for radiation therapy planning in gliomas, meningiomas and prostate cancer (see above and [239]), radiotracers showing specific aspects of tumour biology such as proliferative activity and cancer-associated fibroblasts might be of relevance for biological target definition. The most commonly used radiopharmaceutical for imaging cell proliferation is $\left[{ }^{18} \mathrm{~F}\right] \mathrm{FLT}$ (the use of PET with $\left[{ }^{18} \mathrm{~F}\right] \mathrm{FLT}$ is referred to as FLT-PET in the following text) [240]. Contrary to FDG-, FLT-PET identifies the proliferating cell 
compartment within the GTV and could potentially be used to define tumour sub-volumes with high proliferative activity. Escalation of radiation dose within these regions could improve the tumour control probability by diminishing accelerated repopulation [53]. Several investigators evaluated the effectiveness of FLT-PET for radiotherapy planning in oropharyngeal tumours, oesophageal carcinoma, and NSCLC but it has not found its way into clinical routine [241, 242]. In recent years, more promising is a novel group of tracers targeting the fibroblast activation protein (FAP) on the so-called cancer-associated fibroblasts (CAFs), such as $\left[{ }^{68} \mathrm{Ga}\right] \mathrm{Ga}-\mathrm{FAPI}$ [243]. Due to its high tumour to background contrast in many malignancies, which often is superior to that for $\left[{ }^{18} \mathrm{~F}\right] \mathrm{FDG}$, there is also rising interest in the use of FAP-specific PET for radiation treatment planning [244, 245]. Promising first preliminary results in HNSCC with $\left[{ }^{68} \mathrm{Ga}\right] \mathrm{Ga}-\mathrm{FAPI}$ and PET suggest it might help in accurately assessing the extent of tumour spread prior to treatment start to reduce the area exposed to radiation and thereby reduce toxicities [245]. An optimized radiation therapy planning and reduction of the treatment field is also reported in lung cancer where differentiating tumour from normal tissue is often difficult with $\left[{ }^{18} \mathrm{~F}\right] \mathrm{FDG}$ in particular when the lung is affected by inflammatory conditions or chronic obstructive pulmonary disease [246]. However, large prospective trials are necessary to define the future role of FAPI-PET for radiation therapy planning [247].

There has also been significant progress in imaging with radiolabelled antibodies and antibody fragments. Labelling of these proteins with ${ }^{89} \mathrm{Zr}$ via the chelator DFO is a routine process, which only rarely affects their ligand binding properties. Clinical studies have shown that radiolabelled antibodies allow for imaging of a variety of important targets including, for example, HER2, CA19-9, and PD-L1 [248-250]. Using these antibodies PET imaging may therefore reveal biological changes during radiotherapy, e.g. the up- or down-regulation of PD-L1. Broader clinical use of radiolabelled antibodies is currently limited by the significantly higher radiation dose from the long-lived isotope ${ }^{89} \mathrm{Zr}$. However, PET/CT systems with several fold higher sensitivity than existing scanners are currently entering the clinic. These systems allow imaging with radiolabelled antibodies at radiation doses similar to FDG-PET/CT [251].

\section{PET-based dose painting}

Imaging biomarkers measured with hypoxia tracers such as $\left[{ }^{18} \mathrm{~F}\right] \mathrm{FMISO}$ and $\left[{ }^{18} \mathrm{~F}\right] \mathrm{FAZA}$ but also with routine $\left[{ }^{18} \mathrm{~F}\right] \mathrm{FDG}$ have been shown to be prognostic for outcome after radiotherapy [43, 46, 48, 209, 252-256]. Consequently, radiation treatment adaptation by means of PET-guided dose escalation or de-escalation to account for individual radiation sensitivities in tumour sub-regions, so-called dose painting, seems attractive and might enable for increased tumour control rates and/or reduced toxicity [51, 252, 257]. Final results from randomized studies are necessary to estimate the full potential of PET-based dose painting RT [51, 252, 258, 259].

\section{Reimbursement}

Unfortunately, only few of the presented, internationally accepted indications for PET/CT are currently recognized and reimbursed by German statutory health insurances in the (outpatient) setting. A more thorough discussion of this delicate issue can be found in [260]. However, the authors of this article are convinced that this technique is a very powerful tool for optimal patient care and therefore hope for future adjustment of reimbursement regulations to allow for excellent patient care in accordance with (international) recommendations and guidelines.

\section{Conclusions}

In conclusion, PET/CT is an established tool for radiation therapy planning of various tumour entities in different clinical scenarios. Large multi-centre, prospective trails are needed to further enhance evidence for improved oncological outcomes due to incorporation of this imaging technique into patient management.

\begin{abstract}
Members of Arbeitsgemeinschaft Nuklearmedizin und Strahlentherapie der DEGRO und DGN Constantin Lapa, Ursula Nestle, Nathalie L. Albert, Christian Baues, Ambros Beer, Andreas Buck, Volker Budach, Rebecca Bütof, Stephanie E. Combs, Thorsten Derlin, Matthias Eiber, Wolfgang P. Fendler, Christian Furth, Cihan Gani, Eleni Gkika, Anca-L. Grosu, Christoph Henkenberens, Harun Ilhan, Steffen Löck, Simone Marnitz-Schulze, Matthias Miederer, Michael Mix, Nils H. Nicolay, Maximilian Niyazi, Christoph Pöttgen, Claus M. Rödel, Imke Schatka, Sarah M. Schwarzenboeck, Andrei S. Todica, Wolfgang Weber, Simone Wegen, Thomas Wiegel, Constantinos Zamboglou, Daniel Zips, Klaus Zöphel, Sebastian Zschaeck, Daniela Thorwarth, Esther G.C. Troost

Conflict of interest W. P. Fendler is a consultant for BTG, and he received fees from RadioMedix, Bayer, and Parexel outside of the submitted work. C. Lapa, U. Nestle, N.L. Albert, C. Baues, A. Beer, A. Buck, V. Budach, R. Bütof, S.E. Combs, T. Derlin, M. Eiber, C. Furth, C. Gani, E. Gkika, A.-L. Grosu, C. Henkenberens, H. Ilhan, S. Löck, S. Marnitz-Schulze, M. Miederer, M. Mix, N.H. Nicolay, M. Niyazi, C. Pöttgen, C.M. Rödel, I. Schatka, S.M. Schwarzenboeck, A.S. Todica, W. Weber, S. Wegen, T. Wiegel, C. Zamboglou, D. Zips, K. Zöphel, S. Zschaeck, D. Thorwarth and E.G. C. Troost declare that they have no competing interests.
\end{abstract}

\section{References}

1. Takenaka S, Asano Y, Shinoda J, Nomura Y, Yonezawa S, Miwa K, Yano H, Iwama T (2014) Comparison of 11C-methionine, 11C- 
choline, and 18F-fluorodeoxyglucose-positron emission tomography for distinguishing glioma recurrence from radiation necrosis. Neurol Med Chir (Tokyo) 54(4):280-289. https://doi.org/10.2176/ nmc.oa2013-0117

2. Nihashi T, Dahabreh IJ, Terasawa T (2013) Diagnostic accuracy of PET for recurrent glioma diagnosis: a meta-analysis. AJNR Am J Neuroradiol 34(5):944. https://doi.org/10.3174/ajnr.A3324

3. Karunanithi S, Sharma P, Kumar A, Khangembam BC, Bandopadhyaya GP, Kumar R, Gupta DK, Malhotra A, Bal C (2013) ${ }^{18} \mathrm{~F}$-FDOPA PET/CT for detection of recurrence in patients with glioma: prospective comparison with ${ }^{18} \mathrm{~F}-\mathrm{FDG}$ PET/CT. Eur $\mathrm{J}$ Nucl Med Mol Imaging 40(7):1025-1035. https://doi.org/10.1007/ s00259-013-2384-0

4. Albert NL, Weller M, Suchorska B, Galldiks N, Soffietti R, Kim MM, la Fougère C, Pope W, Law I, Arbizu J, Chamberlain MC, Vogelbaum M, Ellingson BM, Tonn JC (2016) Response Assessment in Neuro-Oncology working group and European Association for Neuro-Oncology recommendations for the clinical use of PET imaging in gliomas. Neuro-Oncology 18(9):1199-1208. https://doi.org/10.1093/neuonc/now058

5. Galldiks N, Langen K-J, Albert NL, Chamberlain M, Soffietti R, Kim MM, Law I, Le Rhun E, Chang S, Schwarting J, Combs SE, Preusser M, Forsyth P, Pope W, Weller M, Tonn JC (2019) PET imaging in patients with brain metastasis-Report of the RANO/PET group. Neuro Oncol 21(5):585-595. https://doi.org/ 10.1093/neuonc/noz003

6. Galldiks N, Albert NL, Sommerauer M, Grosu AL, Ganswindt U, Law I, Preusser M, Le Rhun E, Vogelbaum MA, Zadeh G, Dhermain F, Weller M, Langen K-J, Tonn JC (2017) PET imaging in patients with meningioma-Report of the RANO/PET group. Neuro Oncol 19(12):1576-1587. https://doi.org/10.1093/neuonc/nox112

7. Kracht LW, Miletic H, Busch S, Jacobs AH, Voges J, Hoevels M, Klein JC, Herholz K, Heiss W-D (2004) Delineation of brain tumor extent with [11C]1-methionine positron emission tomography. Clin Cancer Res 10(21):7163. https://doi.org/10.1158/1078-0432.CCR04-0262

8. Pauleit D, Floeth F, Hamacher K, Riemenschneider MJ, Reifenberger G, Müller H-W, Zilles K, Coenen HH, Langen K-J (2005) O-(2-[18F]fluoroethyl)-l-tyrosine PET combined with MRI improves the diagnostic assessment of cerebral gliomas. Brain 128(3):678-687. https://doi.org/10.1093/brain/awh399

9. Pafundi DH, Laack NN, Youland RS, Parney IF, Lowe VJ, Giannini C, Kemp BJ, Grams MP, Morris JM, Hoover JM, Hu LS, Sarkaria JN, Brinkmann DH (2013) Biopsy validation of ${ }^{18} \mathrm{~F}$-DOPA PET and biodistribution in gliomas for neurosurgical planning and radiotherapy target delineation: results of a prospective pilot study. Neuro Oncol 15(8):1058-1067. https://doi.org/10.1093/neuonc/ not002

10. Roodakker KR, Alhuseinalkhudhur A, Al-Jaff M, Georganaki M, Zetterling M, Berntsson SG, Danfors T, Strand R, Edqvist P-H, Dimberg A, Larsson E-M, Smits A (2019) Region-by-region analysis of PET, MRI, and histology in en bloc-resected oligodendrogliomas reveals intra-tumoral heterogeneity. Eur J Nucl Med Mol Imaging 46(3):569-579. https://doi.org/10.1007/s00259-0184107-z

11. Verburg N, Koopman T, Yaqub MM, Hoekstra OS, Lammertsma AA Barkhof F, Pouwels PJW, Reijneveld JC, Heimans JJ, Rozemuller AJM, Bruynzeel AME, Lagerwaard F, Vandertop WP, Boellaard R, Wesseling P, de Witt Hamer PC (2019) Improved detection of diffuse glioma infiltration with imaging combinations: a diagnostic accuracy study. Neuro-Oncology 22(3):412-422. https://doi. org/10.1093/neuonc/noz180

12. Schön SCJ, Liesche-Starnecker F, Molina-Romero M, Eichinger P, Metz M, Karimov I, Preibisch C, Keupp J, Hock A, Meyer B, Weber W, Zimmer C, Pyka T, Yakushev I, Gempt J, Wiestler B (2020) Imaging glioma biology: spatial comparison of amino acid PET, amide proton transfer, and perfusion-weighted MRI in newly diagnosed gliomas. Eur J Nucl Med Mol Imaging 47(6):1468-1475. https://doi.org/10.1007/s00259-019-04677-x

13. Fleischmann DF, Unterrainer M, Schön R, Corradini S, Maihöfer C, Bartenstein P, Belka C, Albert NL, Niyazi M (2020) Margin reduction in radiotherapy for glioblastoma through $18 \mathrm{~F}$ fluoroethyltyrosine PET?-A recurrence pattern analysis. Radiother Oncol 145:49-55. https://doi.org/10.1016/j.radonc.2019.12. 005

14. Møller S, Munck af Rosenschöld P, Costa J, Law I, Poulsen HS, Engelholm SA, Engelholm S (2017) Toxicity and efficacy of reirradiation of high-grade glioma in a phase I dose- and volume escalation trial. Radiother Oncol 125(2):223-227. https://doi.org/10. 1016/j.radonc.2017.09.039

15. Grosu A-L, Astner ST, Riedel E, Nieder C, Wiedenmann N, Heinemann F, Schwaiger M, Molls M, Wester H-J, Weber WA (2011) An interindividual comparison of O-(2- [18F]Fluoroethyl)L-Tyrosine (FET)- and L-[methyl-11C]Methionine (MET)-PET in patients with brain gliomas and metastases. Int J Radiat Oncol 81(4):1049-1058. https://doi.org/10.1016/j.ijrobp.2010.07.002

16. Popp I, Bott S, Mix M, Oehlke O, Schimek-Jasch T, Nieder C, Nestle U, Bock M, Yuh WTC, Meyer PT, Weber WA, Urbach H, Mader I, Grosu A-L (2019) Diffusion-weighted MRI and ADC versus FET-PET and GdT1w-MRI for gross tumor volume (GTV) delineation in re-irradiation of recurrent glioblastoma. Radiother Oncol 130:121-131. https://doi.org/10.1016/j.radonc.2018.08.019

17. Grosu AL, Weber WA, Franz M, Stärk S, Piert M, Thamm R, Gumprecht H, Schwaiger M, Molls M, Nieder C (2005) Reirradiation of recurrent high-grade gliomas using amino acid PET (SPECT)/CT/MRI image fusion to determine gross tumor volume for stereotactic fractionated radiotherapy. Int J Radiat Oncol Biol Phys 63(2):511-519. https://doi.org/10.1016/j.ijrobp.2005.01.056

18. Oehlke O, Mix M, Graf E, Schimek-Jasch T, Nestle U, Götz I, Schneider-Fuchs S, Weyerbrock A, Mader I, Baumert BG, Short SC, Meyer PT, Weber WA, Grosu A-L (2016) Amino-acid PET versus MRI guided re-irradiation in patients with recurrent glioblastoma multiforme (GLIAA) - Protocol of a randomized phase II trial (NOA 10/ARO 2013-1). BMC Cancer 16(1):769. https://doi.org/ 10.1186/s12885-016-2806-Z

19. Gehler B, Paulsen F, Öksüz MÖ, Hauser T-K, Eschmann SM, Bares R, Pfannenberg C, Bamberg M, Bartenstein P, Belka C, Ganswindt U (2009) ${ }^{68} \mathrm{Ga}$ ]-DOTATOC-PET/CT for meningioma IMRT treatment planning. Radiat Oncol 4(1):56. https://doi.org/10.1186/ 1748-717X-4-56

20. Nyuyki F, Plotkin M, Graf R, Michel R, Steffen I, Denecke T, Geworski L, Fahdt D, Brenner W, Wurm R (2010) Potential impact of 68Ga-DOTATOC PET/CT on stereotactic radiotherapy planning of meningiomas. Eur J Nucl Med Mol Imaging 37(2):310-318. https://doi.org/10.1007/s00259-009-1270-2

21. Kunz WG, Jungblut LM, Kazmierczak PM, Vettermann FJ, Bollenbacher A, Tonn JC, Schichor C, Rominger A, Albert NL, Bartenstein P, Reiser MF, Cyran CC (2017) Improved detection of transosseous meningiomas using ${ }^{68} \mathrm{Ga}$-DOTATATE PET/CT compared with contrast-enhanced MRI. J Nucl Med 58(10):1580. https://doi. org/10.2967/jnumed.117.191932

22. Galldiks NNM, Grosu AL, Kocher M, Langen K-J, Law I, Minniti G, Kim MM, Tsien C, Dhermain F et al (2021) Contribution of PET imaging to radiotherapy planning and monitoring in glioma patients-A report of the PET/RANO group. Neuro Oncol 23(6):881-893. https://doi.org/10.1093/neuonc/noab013

23. Spence AM, Muzi M, Graham MM, O'Sullivan F, Link JM, Lewellen TK, Lewellen B, Freeman SD, Mankoff DA, Eary JF, Krohn KA (2002) 2- $\left[{ }^{18}\right.$ F]Fluoro-2-deoxyglucose and glucose uptake in malignant gliomas before and after radiotherapy. Clin Cancer Res 8(4):971 
24. Charnley N, West CM, Barnett CM, Brock C, Bydder GM, Glaser M, Newlands ES, Swindell R, Matthews J, Price P (2006) Early change in glucose metabolic rate measured using FDG-PET in patients with high-grade glioma predicts response to temozolomide but not temozolomide plus radiotherapy. Int $\mathrm{J}$ Radiat Oncol Biol Phys 66(2):331-338. https://doi.org/10.1016/j.ijrobp.2006.04. 043

25. Galldiks N, Langen K-J, Holy R, Pinkawa M, Stoffels G, Nolte KW, Kaiser HJ, Filss CP, Fink GR, Coenen HH, Eble MJ, Piroth MD (2012) Assessment of treatment response in patients with glioblastoma using O-(2-18F-Fluoroethyl)-1-tyrosine PET in comparison to MRI. J Nucl Med 53(7):1048. https://doi.org/10.2967/jnumed.111. 098590

26. Piroth MD, Pinkawa M, Holy R, Klotz J, Nussen S, Stoffels G, Coenen HH, Kaiser HJ, Langen KJ, Eble MJ (2011) Prognostic value of early $\left[{ }^{18} \mathrm{~F}\right]$ Fluoroethyltyrosine positron emission tomography after radiochemotherapy in glioblastoma multiforme. Int J Radiat Oncol Biol Phys 80(1):176-184. https://doi.org/10.1016/j.ijrobp.2010. 01.055

27. Wang Y, Rapalino O, Heidari P, Loeffler J, Shih HA, Oh K, Mahmood U (2018) C11 Methionine PET (MET-PET) imaging of glioblastoma for detecting postoperative residual disease and response to chemoradiation therapy. Int J Radiat Oncol Biol Phys 102(4):1024-1028. https://doi.org/10.1016/j.ijrobp.2018.06.011

28. Miller S, Li P, Schipper M, Junck L, Piert M, Lawrence TS, Tsien C, Cao Y, Kim MM (2020) Metabolic tumor volume response assessment using (11) C-methionine positron emission tomography identifies glioblastoma tumor subregions that predict progression better than baseline or anatomic magnetic resonance imaging alone. Adv Radiat Oncol 5(1):53-61. https://doi.org/10.1016/j.adro.2019. 08.004

29. Fleischmann DF, Unterrainer M, Bartenstein P, Belka C, Albert NL, Niyazi M (2017) (18)F-FET PET prior to recurrent high-grade glioma re-irradiation-additional prognostic value of dynamic timeto-peak analysis and early static summation images? J Neurooncol 132(2):277-286. https://doi.org/10.1007/s11060-016-2366-8

30. Dhermain FG, Hau P, Lanfermann H, Jacobs AH, van den Bent MJ (2010) Advanced MRI and PET imaging for assessment of treatment response in patients with gliomas. Lancet Neurol 9(9):906-920. https://doi.org/10.1016/S1474-4422(10)70181-2

31. Kumar AJ, Leeds NE, Fuller GN, Tassel PV, Maor MH, Sawaya RE, Levin VA (2000) Malignant gliomas: MR imaging spectrum of radiation therapy- and chemotherapy-induced necrosis of the brain after treatment. Radiology 217(2):377-384. https://doi.org/10. 1148/radiology.217.2.r00nv36377

32. Langen K-J, Galldiks N, Hattingen E, Shah NJ (2017) Advances in neuro-oncology imaging. Nat Rev Neurol 13(5):279-289. https:// doi.org/10.1038/nrneurol.2017.44

33. Galldiks N, Stoffels G, Filss C, Rapp M, Blau T, Tscherpel C, Ceccon G, Dunkl V, Weinzierl M, Stoffel M, Sabel M, Fink GR, Shah NJ, Langen K-J (2015) The use of dynamic O-(2-18F-fluoroethyl)-1-tyrosine PET in the diagnosis of patients with progressive and recurrent glioma. Neuro-Oncology 17(9):1293-1300. https:// doi.org/10.1093/neuonc/nov088

34. Pyka T, Hiob D, Preibisch C, Gempt J, Wiestler B, Schlegel J, Straube C, Zimmer C (2018) Diagnosis of glioma recurrence using multiparametric dynamic ${ }^{18} \mathrm{~F}$-fluoroethyl-tyrosine PET-MRI. Eur J Radiol 103:32-37. https://doi.org/10.1016/j.ejrad.2018.04.003

35. Werner J-M, Stoffels G, Lichtenstein T, Borggrefe J, Lohmann P, Ceccon G, Shah NJ, Fink GR, Langen K-J, Kabbasch C, Galldiks N (2019) Differentiation of treatment-related changes from tumour progression: a direct comparison between dynamic FET PET and ADC values obtained from DWI MRI. Eur J Nucl Med Mol Imaging 46(9):1889-1901. https://doi.org/10.1007/s00259-019-043847
36. Caldas-Magalhaes J, Kasperts N, Kooij N, van den Berg CAT, Terhaard CHJ, Raaijmakers CPJ, Philippens MEP (2012) Validation of imaging with pathology in laryngeal cancer: accuracy of the registration methodology. Int $\mathrm{J}$ Radiat Oncol Biol Phys 82(2):e289-e298. https://doi.org/10.1016/j.ijrobp.2011.05.004

37. Chatterjee S, Frew J, Mott J, McCallum H, Stevenson P, Maxwell R, Wilsdon J, Kelly CG (2012) Variation in radiotherapy target volume definition, dose to organs at risk and clinical target volumes using anatomic (computed tomography) versus combined anatomic and molecular imaging (positron emission tomography/computed tomography): intensity-modulated radiotherapy delivered using a tomotherapy hi art machine: final results of the VortigERN study. Clin Oncol 24(10):e173-e179. https://doi.org/10.1016/j.clon.2012. 09.004

38. Daisne J-F, Duprez T, Weynand B, Lonneux M, Hamoir M, Reychler H, Grégoire V (2004) Tumor volume in pharyngolaryngeal squamous cell carcinoma: comparison at CT, MR imaging, and FDG PET and validation with surgical specimen. Radiology 233(1):93-100. https://doi.org/10.1148/radiol.2331030660

39. Geets X, Daisne J-F, Tomsej M, Duprez T, Lonneux M, Grégoire V (2006) Impact of the type of imaging modality on target volumes delineation and dose distribution in pharyngo-laryngeal squamous cell carcinoma: comparison between pre- and per-treatment studies. Radiother Oncol 78(3):291-297. https://doi.org/10.1016/j.radonc. 2006.01.006

40. Guido A, Fuccio L, Rombi B, Castellucci P, Cecconi A, Bunkheila F, Fuccio C, Spezi E, Angelini AL, Barbieri E (2009) Combined FDGPET/CT imaging in radiotherapy target delineation for head-andneck cancer. Int J Radiat Oncol Biol Phys 73(3):759-763. https:// doi.org/10.1016/j.ijrobp.2008.04.059

41. Leclerc M, Lartigau E, Lacornerie T, Daisne J-F, Kramar A, Grégoire V (2015) Primary tumor delineation based on 18FDG PET for locally advanced head and neck cancer treated by chemo-radiotherapy. Radiother Oncol 116(1):87-93. https://doi.org/10.1016/j. radonc.2015.06.007

42. Wang D, Schultz CJ, Jursinic PA, Bialkowski M, Zhu XR, Brown WD, Rand SD, Michel MA, Campbell BH, Wong S, Li XA, Wilson JF (2006) Initial experience of FDG-PET/CT guided IMRT of headand-neck carcinoma. Int J Radiat Oncol Biol Phys 65(1):143-151. https://doi.org/10.1016/j.ijrobp.2005.11.048

43. Löck S, Perrin R, Seidlitz A, Bandurska-Luque A, Zschaeck S, Zöphel K, Krause M, Steinbach J, Kotzerke J, Zips D, Troost EGC, Baumann M (2017) Residual tumour hypoxia in head-and-neck cancer patients undergoing primary radiochemotherapy, final results of a prospective trial on repeat FMISO-PET imaging. Radiother Oncol 124(3):533-540. https://doi.org/10.1016/j.radonc.2017. 08.010

44. Mortensen LS, Johansen J, Kallehauge J, Primdahl H, Busk M, Lassen P, Alsner J, Sørensen BS, Toustrup K, Jakobsen S, Petersen J, Petersen H, Theil J, Nordsmark M, Overgaard J (2012) FAZA PET/CT hypoxia imaging in patients with squamous cell carcinoma of the head and neck treated with radiotherapy: results from the DAHANCA 24 trial. Radiother Oncol 105(1):14-20. https://doi.org/10.1016/j.radonc.2012.09.015

45. Troost EGC, Laverman P, Philippens MEP, Lok J, van der Kogel AJ, Oyen WJG, Boerman OC, Kaanders JHAM, Bussink J (2008) Correlation of [18F]FMISO autoradiography and pimonodazole immunohistochemistry in human head and neck carcinoma xenografts. Eur J Nucl Med Mol Imaging 35(10):1803-1811. https://doi.org/10.1007/s00259-008-0772-7

46. Zips D, Zöphel K, Abolmaali N, Perrin R, Abramyuk A, Haase R, Appold S, Steinbach J, Kotzerke J, Baumann M (2012) Exploratory prospective trial of hypoxia-specific PET imaging during radiochemotherapy in patients with locally advanced head-and-neck cancer. Radiother Oncol 105(1):21-28. https://doi.org/10.1016/j. radonc.2012.08.019 
47. Grosu A-L, Souvatzoglou M, Röper B, Dobritz M, Wiedenmann N, Jacob V, Wester H-J, Reischl G, Machulla H-J, Schwaiger M, Molls M, Piert M (2007) Hypoxia imaging with FAZA-PET and theoretical considerations with regard to dose painting for individualization of radiotherapy in patients with head and neck cancer. Int J Radiat Oncol Biol Phys 69(2):541-551. https://doi.org/10.1016/j. ijrobp.2007.05.079

48. Wiedenmann N, Grosu A-L, Büchert M, Rischke HC, Ruf J, Bielak L, Majerus L, Rühle A, Bamberg F, Baltas D, Hennig J, Mix M, Bock M, Nicolay NH (2020) The utility of multiparametric MRI to characterize hypoxic tumor subvolumes in comparison to FMISO PET/CT. Consequences for diagnosis and chemoradiation treatment planning in head and neck cancer. Radiother Oncol 150:128-135. https://doi.org/10.1016/j.radonc.2020.06.013

49. Nicolay NH, Wiedenmann N, Mix M, Weber WA, Werner M, Grosu AL, Kayser G (2020) Correlative analyses between tissuebased hypoxia biomarkers and hypoxia PET imaging in head and neck cancer patients during radiochemotherapy-Results from a prospective trial. Eur J Nucl Med Mol Imaging 47(5):1046-1055. https://doi.org/10.1007/s00259-019-04598-9

50. Rühle A, Grosu A-L, Wiedenmann N, Mix M, Stoian R, Niedermann G, Baltas D, Werner M, Weber WA, Kayser G, Nicolay NH (2020) Hypoxia dynamics on FMISO-PET in combination with PD-1/PD-L1 expression has an impact on the clinical outcome of patients with head-and-neck squamous cell carcinoma undergoing chemoradiation. Theranostics 10(20):9395-9406. https://doi.org/ 10.7150/thno. 48392

51. Riaz N, Sherman E, Pei X, Schöder H, Grkovski M, Paudyal R, Katabi N, Selenica P, Yamaguchi TN, Ma D, Lee SK, Shah R, Kumar R, Kuo F, Ratnakumar A, Aleynick N, Brown D, Zhang Z, Hatzoglou V, Liu LY, Salcedo A, Tsai CJ, McBride S, Morris LGT, Boyle J, Singh B, Higginson DS, Damerla RR, Paula AC, Price K, Moore EJ, Garcia JJ, Foote R, Ho A, Wong RJ, Chan TA, Powell SN, Boutros PC, Humm JL, Shukla-Dave A, Pfister D, ReisFilho JS, Lee N (2021) Precision radiotherapy: reduction in radiation for oropharyngeal cancer in the $30 \mathrm{ROC}$ trial. J Natl Cancer Inst. https://doi.org/10.1093/jnci/djaa184

52. Hoeben BAW, Troost EGC, Span PN, van Herpen CML, Bussink J, Oyen WJG, Kaanders JHAM (2013) ${ }^{18}$ F-FLT PET during radiotherapy or chemoradiotherapy in head and neck squamous cell carcinoma is an early predictor of outcome. J Nucl Med 54(4):532. https://doi.org/10.2967/jnumed.112.105999

53. Troost EGC, Bussink J, Hoffmann AL, Boerman OC, Oyen WJG, Kaanders JHAM (2010) ${ }^{18}$ F-FLT PET/CT for early response monitoring and dose escalation in oropharyngeal tumors. J Nucl Med 51(6):866. https://doi.org/10.2967/jnumed.109.069310

54. Troost EGC, Vogel WV, Merkx MAW, Slootweg PJ, Marres HAM, Peeters WJM, Bussink J, van der Kogel AJ, Oyen WJG, Kaanders JHAM (2007) ${ }^{18}$ F-FLT PET does not discriminate between reactive and metastatic lymph nodes in primary head and neck cancer patients. J Nucl Med 48(5):726. https://doi.org/10.2967/jnumed. 106.037473

55. Syed M, Flechsig P, Liermann J, Windisch P, Staudinger F, Akbaba S, Koerber SA, Freudlsperger C, Plinkert PK, Debus J, Giesel F, Haberkorn U, Adeberg S (2020) Fibroblast activation protein inhibitor (FAPI) PET for diagnostics and advanced targeted radiotherapy in head and neck cancers. Eur J Nucl Med Mol Imaging 47(12):2836-2845. https://doi.org/10.1007/s00259-02004859-y

56. Machado Medeiros T, Altmayer S, Watte G, Zanon M, Basso Dias A, Henz Concatto N, Hoefel Paes J, Mattiello R, de Souza Santos F, Mohammed T-L, Verma N, Hochhegger B (2020) 18FFDG PET/CT and whole-body MRI diagnostic performance in M staging for non-small cell lung cancer: a systematic review and meta-analysis. Eur Radiol 30(7):3641-3649. https://doi.org/10. 1007/s00330-020-06703-1
57. Madsen PH, Holdgaard PC, Christensen JB, Høilund-Carlsen PF (2016) Clinical utility of F-18 FDG PET-CT in the initial evaluation of lung cancer. Eur J Nucl Med Mol Imaging 43(11):2084-2097. https://doi.org/10.1007/s00259-016-3407-4

58. Nestle U, Schimek-Jasch T, Kremp S, Schaefer-Schuler A, Mix M, Küsters A, Tosch M, Hehr T, Eschmann SM, Bultel Y-P, Hass P, Fleckenstein J, Thieme A, Stockinger M, Dieckmann K, Miederer M, Holl G, Rischke HC, Gkika E, Adebahr S, König J, Grosu A-L (2020) Imaging-based target volume reduction in chemoradiotherapy for locally advanced non-small-cell lung cancer (PET-Plan): a multicentre, open-label, randomised, controlled trial. Lancet Oncol 21(4):581-592. https://doi.org/10.1016/S1470-2045(20)300139

59. Konert T, Everitt S, La Fontaine MD, van de Kamer JB, MacManus MP, Vogel WV, Callahan J, Sonke J-J (2020) Robust, independent and relevant prognostic $18 \mathrm{~F}$-fluorodeoxyglucose positron emission tomography radiomics features in non-small cell lung cancer: are there any? PLoS ONE 15(2):e228793. https://doi.org/ 10.1371/journal.pone. 0228793

60. Nestle U, De Ruysscher D, Ricardi U, Geets X, Belderbos J, Pöttgen C, Dziadiuszko R, Peeters S, Lievens Y, Hurkmans C, Slotman B, Ramella S, Faivre-Finn C, McDonald F, Manapov F, Putora PM, LePéchoux C, Van Houtte P (2018) ESTRO ACROP guidelines for target volume definition in the treatment of locally advanced non-small cell lung cancer. Radiother Oncol 127(1):1-5. https://doi.org/10.1016/j.radonc.2018.02.023

61. Kong F-M, Ten Haken RK, Schipper M, Frey KA, Hayman J, Gross M, Ramnath N, Hassan KA, Matuszak M, Ritter T, Bi N, Wang W, Orringer M, Cease KB, Lawrence TS, Kalemkerian GP (2017) Effect of midtreatment PET/CT-adapted radiation therapy with concurrent chemotherapy in patients with locally advanced non-small-cell lung cancer: a phase 2 clinical trial. JAMA Oncol 3(10):1358-1365. https://doi.org/10.1001/jamaoncol.2017.0982

62. Pöttgen C, Gauler T, Bellendorf A, Guberina M, Bockisch A, Schwenzer N, Heinzelmann F, Cordes S, Schuler MH, Welter S, Stamatis G, Friedel G, Darwiche K, Jöckel K-H, Eberhardt W, Stuschke M (2016) Standardized uptake decrease on $\left[{ }^{18} \mathrm{~F}\right]-$ Fluorodeoxyglucose positron emission tomography after Neoadjuvant chemotherapy is a prognostic classifier for long-term outcome after multimodality treatment: secondary analysis of a randomized trial for resectable stage IIIA/B non-small-cell lung cancer. J Clin Oncol 34(21):2526-2533. https://doi.org/10.1200/jco.2015.65.5167

63. RTOG 1106/ACRIN 6697 Randomized phase II trial of individualized adaptive radiotherapy using during treatment FDGPET/CT and modern technology in locally advanced non-small cell lung cancer (NSCLC). https://clinicaltrials.gov/ct2/show/ NCT01507428. Accessed: mid-January 2021

64. Dissaux G, Visvikis D, Da-ano R, Pradier O, Chajon E, Barillot I, Duvergé L, Masson I, Abgral R, Santiago Ribeiro M-J, Devillers A, Pallardy A, Fleury V, Mahé M-A, De Crevoisier R, Hatt M, Schick U (2020) Pretreatment ${ }^{18}$ F-FDG PET/CT radiomics predict local recurrence in patients treated with stereotactic body radiotherapy for early-stage non-small cell lung cancer: a multicentric study. J Nucl Med 61(6):814. https://doi.org/10.2967/jnumed. 119.228106

65. Wang D, Zhang M, Gao X, Yu L (2016) Prognostic value of baseline 18F-FDG PET/CT functional parameters in patients with advanced lung adenocarcinoma stratified by EGFR mutation status. PLoS ONE 11(6):e158307. https://doi.org/10.1371/journal.pone. 0158307

66. Bissonnette J-P, Yap ML, Clarke K, Shessel A, Higgins J, Vines D, Atenafu EG, Becker N, Leavens C, Bezjak A, Jaffray DA, Sun A (2018) Serial 4DCT/4DPET imaging to predict and monitor response for locally-advanced non-small cell lung cancer chemoradiotherapy. Radiother Oncol 126(2):347-354. https://doi.org/10. 1016/j.radonc.2017.11.023 
67. van Elmpt W, Öllers M, Dingemans A-MC, Lambin P, De Ruysscher D (2012) Response assessment using 18F-FDG PET early in the course of radiotherapy correlates with survival in advancedstage non-small cell lung cancer. J Nucl Med 53(10):1514. https:// doi.org/10.2967/jnumed.111.102566

68. Ganem J, Thureau S, Gouel P, Dubray B, Salaun M, Texte E, Vera P (2019) Prognostic value of post-induction chemotherapy 18F-FDG PET-CT in stage II/III non-small cell lung cancer before (chemo)radiation. PLoS ONE 14(10):e222885. https://doi.org/10.1371/ journal.pone. 0222885

69. Luo Y, McShan D, Ray D, Matuszak M, Jolly S, Lawrence T, Kong FM, Haken RT, Naqa IE (2019) Development of a fully crossvalidated Bayesian network approach for local control prediction in lung cancer. IEEE Trans Radiat Plasma Med Sci 3(2):232-241. https://doi.org/10.1109/TRPMS.2018.2832609

70. Roengvoraphoj O, Wijaya C, Eze C, Li M, Dantes M, Taugner J, Tufman A, Huber RM, Belka C, Manapov F (2018) Analysis of primary tumor metabolic volume during chemoradiotherapy in locally advanced non-small cell lung cancer. Strahlenther Onkol 194(2):107-115. https://doi.org/10.1007/s00066-017-1229-3

71. Bowen SR, Hippe DS, Chaovalitwongse WA, Duan C, Thammasorn P, Liu X, Miyaoka RS, Vesselle HJ, Kinahan PE, Rengan R, Zeng J (2019) Voxel forecast for precision oncology: predicting spatially variant and multiscale cancer therapy response on longitudinal quantitative molecular imaging. Clin Cancer Res 25(16):5027. https://doi.org/10.1158/1078-0432.CCR-18-3908

72. Duan C, Chaovalitwongse WA, Bai F, Hippe DS, Wang S, Thammasorn P, Pierce LA, Liu X, You J, Miyaoka RS, Vesselle HJ, Kinahan PE, Rengan R, Zeng J, Bowen SR (2020) Sensitivity analysis of FDG PET tumor voxel cluster radiomics and dosimetry for predicting mid-chemoradiation regional response of locally advanced lung cancer. Phys Med Biol 65(20):205007. https://doi. org/10.1088/1361-6560/abb0c7

73. Zegers CML, van Elmpt W, Reymen B, Even AJG, Troost EGC, Öllers MC, Hoebers FJP, Houben RMA, Eriksson J, Windhorst AD, Mottaghy FM, De Ruysscher D, Lambin P (2014) in vivo quantification of hypoxic and metabolic status of NSCLC tumors using $\left[{ }^{18} \mathrm{~F}\right] \mathrm{HX} 4$ and $\left[{ }^{18} \mathrm{~F}\right] \mathrm{FDG}-\mathrm{PET} / \mathrm{CT}$ imaging. Clin Cancer Res 20(24):6389. https://doi.org/10.1158/1078-0432.CCR-14-1524

74. Bollineni VR, Kerner GSMA, Pruim J, Steenbakkers RJHM, Wiegman EM, Koole MJB, de Groot EH, Willemsen ATM, Luurtsema G, Widder J, Groen HJM, Langendijk JA (2013) PET imaging of tumor hypoxia using ${ }^{18} \mathrm{~F}$-Fluoroazomycin arabinoside in stage III-IV non-small cell lung cancer patients. J Nucl Med 54(8):1175. https:// doi.org/10.2967/jnumed.112.115014

75. Bollineni VR, Koole MJB, Pruim J, Brouwer CL, Wiegman EM, Groen HJM, Vlasman R, Halmos GB, Oosting SF, Langendijk JA, Widder J, Steenbakkers RJHM (2014) Dynamics of tumor hypoxia assessed by 18F-FAZA PET/CT in head and neck and lung cancer patients during chemoradiation: possible implications for radiotherapy treatment planning strategies. Radiother Oncol 113(2):198-203. https://doi.org/10.1016/j.radonc.2014.10.010

76. Everitt S, Ball D, Hicks RJ, Callahan J, Plumridge N, Trinh J, Herschtal A, Kron T, Mac Manus M (2017) Prospective study of serial imaging comparing fluorodeoxyglucose positron emission tomography (PET) and fluorothymidine PET during radical Chemoradiation for non-small cell lung cancer: reduction of detectable proliferation associated with worse survival. Int J Radiat Oncol Biol Phys 99(4):947-955. https://doi.org/10.1016/j.ijrobp.2017.07.035

77. Everitt SJ, Ball DL, Hicks RJ, Callahan J, Plumridge N, Collins M, Herschtal A, Binns D, Kron T, Schneider M, MacManus M (2014) Differential (18)F-FDG and (18)F-FLT uptake on serial PET/CT imaging before and during definitive chemoradiation for non-small cell lung cancer. J Nucl Med 55(7):1069-1074. https://doi.org/10. 2967/jnumed.113.131631
78. Kairemo K, Santos EB, Macapinlac HA, Subbiah V (2020) Early response assessment to targeted therapy using $3^{\prime}$-deoxy- $3^{\prime}[(18) \mathrm{F}]$ Fluorothymidine (18F-FLT) PET/CT in lung cancer. Diagnostics 10(1):26

79. Ajani JA, D'Amico TA, Bentrem DJ, Chao J, Corvera C, Das P, Denlinger CS, Enzinger PC, Fanta P, Farjah F, Gerdes H, Gibson M, Glasgow RE, Hayman JA, Hochwald S, Hofstetter WL, Ilson DH, Jaroszewski D, Johung KL, Keswani RN, Kleinberg LR, Leong S, Ly QP, Matkowskyj KA, McNamara M, Mulcahy MF, Paluri RK, Park H, Perry KA, Pimiento J, Poultsides GA, Roses R, Strong VE, Wiesner G, Willett CG, Wright CD, McMillian NR, Pluchino LA (2019) Esophageal and esophagogastric junction cancers, version 2.2019, NCCN clinical practice guidelines in oncology. 17(7):855. https://doi.org/10.6004/jnccn.2019.0033

80. Lordick F, Mariette C, Haustermans K, Obermannová R, Arnold D (2016) Oesophageal cancer: ESMO clinical practice guidelines for diagnosis, treatment and follow-up. Ann Oncol 27:v50-v57. https:// doi.org/10.1093/annonc/mdw329

81. Bedenne L, Michel P, Bouché O, Milan C, Mariette C, Conroy T, Pezet D, Roullet B, Seitz JF, Herr JP, Paillot B, Arveux P, Bonnetain F, Binquet C (2007) Chemoradiation followed by surgery compared with chemoradiation alone in squamous cancer of the esophagus: FFCD 9102. J Clin Oncol 25(10):1160-1168. https:// doi.org/10.1200/jco.2005.04.7118

82. Stahl M, Stuschke M, Lehmann N, Meyer HJ, Walz MK, Seeber S, Klump B, Budach W, Teichmann R, Schmitt M, Schmitt G, Franke C, Wilke H (2005) Chemoradiation with and without surgery in patients with locally advanced squamous cell carcinoma of the esophagus. J Clin Oncol 23(10):2310-2317. https:// doi.org/10.1200/jco.2005.00.034

83. van Hagen P, Hulshof MCCM, van Lanschot JJB, Steyerberg EW, Henegouwen MIB, Wijnhoven BPL, Richel DJ, Nieuwenhuijzen GAP, Hospers GAP, Bonenkamp JJ, Cuesta MA, Blaisse RJB, Busch ORC, ten Kate FJW, Creemers G-J, Punt CJA, Plukker JTM, Verheul HMW, Bilgen EJS, van Dekken H, van der Sangen MJC, Rozema T, Biermann K, Beukema JC, Piet AHM, van Rij CM, Reinders JG, Tilanus HW, van der Gaast A (2012) Preoperative chemoradiotherapy for esophageal or junctional cancer. N Engl J Med 366(22):2074-2084. https://doi.org/10.1056/NEJMoa1112088

84. Nowee ME, Voncken FEM, Kotte ANTJ, Goense L, van Rossum PSN, van Lier ALHMW, Heijmink SW, Aleman BMP, Nijkamp J, Meijer GJ, Lips IM (2019) Gross tumour delineation on computed tomography and positron emission tomography-computed tomography in oesophageal cancer: a nationwide study. Clin Transl Radiat Oncol 14:33-39. https://doi.org/10.1016/j.ctro.2018. 10.003

85. Thomas L, Lapa C, Bundschuh RA, Polat B, Sonke J-J, Guckenberger M (2015) Tumour delineation in oesophageal cancer-A prospective study of delineation in PET and CT with and without endoscopically placed clip markers. Radiother Oncol 116(2):269-275. https://doi.org/10.1016/j.radonc.2015.07.007

86. Thomas M, Mortensen HR, Hoffmann L, Møller DS, Troost EGC, Muijs CT, Berbee M, Bütof R, Nicholas O, Radhakrishna G, Defraene G, Nafteux P, Nordsmark M, Haustermans K (2021) Proposal for the delineation of neoadjuvant target volumes in oesophageal cancer. Radiother Oncol 156:102-112. https://doi.org/ 10.1016/j.radonc.2020.11.032

87. Metzger J-C, Wollschläger D, Miederer M, Vaupel P, Moehler M, Schmidberger H, Mayer A (2017) Inclusion of PET-CT into planning of primary or neoadjuvant chemoradiotherapy of esophageal cancer improves prognosis. Strahlenther Onkol 193(10):791-799. https://doi.org/10.1007/s00066-017-1164-3

88. Bütof R, Hofheinz F, Zöphel K, Schmollack J, Jentsch C, Zschaeck S, Kotzerke J, van den Hoff J, Baumann M (2019) Prognostic value of standardized uptake ratio in patients with trimodality treatment 
of locally advanced esophageal carcinoma. J Nucl Med 60(2):192. https://doi.org/10.2967/jnumed.117.207670

89. Bütof R, Hofheinz F, Zöphel K, Stadelmann T, Schmollack J, Jentsch C, Löck S, Kotzerke J, Baumann M, van den Hoff J (2015) Prognostic value of pretherapeutic tumor-to-blood standardized uptake ratio in patients with esophageal carcinoma. J Nucl Med 56(8):1150. https://doi.org/10.2967/jnumed.115.155309

90. Hofheinz F, Li Y, Steffen IG, Lin Q, Lili C, Hua W, van den Hoff J, Zschaeck S (2019) Confirmation of the prognostic value of pretherapeutic tumor SUR and MTV in patients with esophageal squamous cell carcinoma. Eur J Nucl Med Mol Imaging 46(7):1485-1494. https://doi.org/10.1007/s00259-019-04307-6

91. Li Y, Beck M, Päßler T, Lili C, Hua W, Mai HD, Amthauer H, Biebl M, Thuss-Patience PC, Berger J, Stromberger C, Tinhofer I, Kruppa J, Budach V, Hofheinz F, Lin Q, Zschaeck S (2020) A FDGPET radiomics signature detects esophageal squamous cell carcinoma patients who do not benefit from chemoradiation. Sci Rep 10(1):17671. https://doi.org/10.1038/s41598-020-74701-w

92. Zschaeck S, Hofheinz F, Zöphel K, Bütof R, Jentsch C, Schmollack J, Löck S, Kotzerke J, Baretton G, Weitz J, Baumann M, Krause M (2017) Increased FDG uptake on late-treatment PET in non-tumour-affected oesophagus is prognostic for pathological complete response and disease recurrence in patients undergoing neoadjuvant radiochemotherapy. Eur J Nucl Med Mol Imaging 44(11):1813-1822. https://doi.org/10.1007/s00259-017-3742-0

93. Zschaeck S, Li Y, Bütof R, Lili C, Hua W, Troost ECG, Beck M, Amthauer H, Kaul D, Kotzerke J, Baur ADJ, Ghadjar P, Baumann M, Krause M, Hofheinz F (2020) Combined tumor plus nontumor interim FDG-PET parameters are prognostic for response to chemoradiation in squamous cell esophageal cancer. Int J Cancer 147(5):1427-1436. https://doi.org/10.1002/ijc.32897

94. Kroese TE, Goense L, van Hillegersberg R, de Keizer B, Mook S, Ruurda JP, van Rossum PSN (2018) Detection of distant interval metastases after neoadjuvant therapy for esophageal cancer with 18F-FDG PET(/CT): a systematic review and meta-analysis. Dis Esophagus. https://doi.org/10.1093/dote/doy055

95. Noordman BJ, Spaander MCW, Valkema R, Wijnhoven BPL, van Berge Henegouwen MI, Shapiro J, Biermann K, van der Gaast A, van Hillegersberg R, Hulshof MCCM, Krishnadath KK, Lagarde SM, Nieuwenhuijzen GAP, Oostenbrug LE, Siersema PD, Schoon EJ, Sosef MN, Steyerberg EW, van Lanschot JJB, Doukas M, Krak NC, Poley J-W, van Rij CM, Bergman JJ, Gisbertz SS, van Laarhoven HWM, Meijer SL, Goense L, Haj Mohammad N, Hobbelink MGG, Offerhaus GJA, Vleggaar F, Curvers WL, Creemers G-J, Roef MJ, van der Sangen MJC, Buijsen J, Riedl RG, Schreurs WMJ, Warmerdam FARM, Janssen MJR, van der Post C, Radema SA, Rosman C, Rütten H (2018) Detection of residual disease after neoadjuvant chemoradiotherapy for oesophageal cancer (preSANO): a prospective multicentre, diagnostic cohort study. Lancet Oncol 19(7):965-974. https://doi.org/10.1016/ S1470-2045(18)30201-8

96. Barbour AP, Walpole ET, Mai GT, Barnes EH, Watson DI, Ackland SP, Martin JM, Burge M, Finch R, Karapetis CS, Shannon J, Nott LM, Varma S, Marx G, Falk GL, Gebski V, Oostendorp M, Wilson K, Thomas J, Lampe G, Zalcberg JR, Simes J, Smithers BM (2020) Preoperative cisplatin, fluorouracil, and docetaxel with or without radiotherapy after poor early response to cisplatin and fluorouracil for resectable oesophageal adenocarcinoma (AGITG DOCTOR): results from a multicentre, randomised controlled phase II trial. Ann Oncol 31(2):236-245. https://doi.org/10.1016/j. annonc.2019.10.019

97. Leitlinienprogramm Onkologie (2018) S3 Leitlinie Diagnostik und Therapie der Plattenepithelkarzinome und Adenokarzinome des Ösophagus, Langversion 2.0. https://www.awmf.org/uploads/tx_ szleitlinien/021-023OLl_Plattenepithel_Adenokarzinom_Oesopha gus_2019-01.pdf. Accessed: mid-January 2021
98. Taylor FG, Quirke P, Heald RJ, Moran BJ, Blomqvist L, Swift IR, Sebag-Montefiore D, Tekkis P, Brown G (2014) Preoperative magnetic resonance imaging assessment of circumferential resection margin predicts disease-free survival and local recurrence: 5-year follow-up results of the MERCURY study. J Clin Oncol 32(1):34-43. https://doi.org/10.1200/jco.2012.45.3258

99. Brown G, Richards CJ, Bourne MW, Newcombe RG, Radcliffe AG, Dallimore NS, Williams GT (2003) Morphologic predictors of lymph node status in rectal cancer with use of high-spatial-resolution MR imaging with histopathologic comparison. Radiology 227(2):371-377. https://doi.org/10.1148/radiol.2272011747

100. Kwak JY, Kim JS, Kim HJ, Ha HK, Yu CS, Kim JC (2012) Diagnostic value of FDG-PET/CT for lymph node metastasis of colorectal cancer. World J Surg 36(8):1898-1905. https://doi.org/10.1007/ s00268-012-1575-3

101. Kim SH, Song B-I, Kim BW, Kim HW, Won KS, Bae SU, Jeong WK, Baek SK (2019) Predictive value of $\left[{ }^{18} \mathrm{~F}\right]$ FDG PET/CT for lymph node metastasis in rectal cancer. Sci Rep 9(1):4979. https://doi.org/10.1038/s41598-019-41422-8

102. Leitlinienprogramm Onkologie (2019) S3-Leitlinie Kolektorales Karzinom, Langversion 2.1. https://www.leitlinienprogrammonkologie.de/fileadmin/user_upload/Downloads/Leitlinien/Kolorek tales_Karzinom/Version_2/LL_KRK_Langversion_2.1.pdf. Accessed: mid-January 2021

103. Gani C, Kirschniak A, Zips D (2019) Watchful waiting after radiochemotherapy in rectal cancer: when is it feasible? Visc Med 35(2):119-123. https://doi.org/10.1159/000499167

104. Roels S, Slagmolen P, Nuyts J, Lee JA, Loeckx D, Maes F, Vandecaveye V, Stroobants S, Ectors N, Penninckx F, Haustermans K (2009) Biological image-guided radiotherapy in rectal cancer: challenges and pitfalls. Int J Radiat Oncol Biol Phys 75(3):782-790. https://doi.org/10.1016/j.ijrobp.2008.11.031

105. Brændengen M, Hansson K, Radu C, Siegbahn A, Jacobsson H, Glimelius B (2011) Delineation of Gross Tumor Volume (GTV) for radiation treatment planning of locally advanced rectal cancer using information from MRI or FDG-PET/CT: a prospective study. Int J Radiat Oncol Biol Phys 81(4):e439-e445. https://doi.org/10.1016/ j.ijrobp.2011.03.031

106. Maas M, Lambregts DMJ, Nelemans PJ, Heijnen LA, Martens MH, Leijtens JWA, Sosef M, Hulsewé KWE, Hoff C, Breukink SO, Stassen L, Beets-Tan RGH, Beets GL (2015) Assessment of clinical complete response after chemoradiation for rectal cancer with digital rectal examination, endoscopy, and MRI: selection for organ-saving treatment. Ann Surg Oncol 22(12):3873-3880. https:// doi.org/10.1245/s10434-015-4687-9

107. Joye I, Debucquoy A, Deroose CM, Vandecaveye V, Cutsem EV, Wolthuis A, D'Hoore A, Sagaert X, Zhou M, Gevaert O, Haustermans K (2017) Quantitative imaging outperforms molecular markers when predicting response to chemoradiotherapy for rectal cancer. Radiother Oncol 124(1):104-109. https://doi.org/10.1016/ j.radonc.2017.06.013

108. Joye I, Deroose CM, Vandecaveye V, Haustermans K (2014) The role of diffusion-weighted MRI and 18F-FDG PET/CT in the prediction of pathologic complete response after radiochemotherapy for rectal cancer: a systematic review. Radiother Oncol 113(2):158-165. https://doi.org/10.1016/j.radonc.2014.11.026

109. Ajani JA, Winter KA, Gunderson LL, Pedersen J, Benson AB, Thomas CR, Mayer RJ, Haddock MG, Rich TA, Willett C (2008) Fluorouracil, mitomycin, and radiotherapy vs fluorouracil, cisplatin, and radiotherapy for carcinoma of the anal canal: a randomized controlled trial. JAMA 299(16):1914-1921. https://doi.org/10. 1001/jama.299.16.1914

110. James RD, Glynne-Jones R, Meadows HM, Cunningham D, Myint AS, Saunders MP, Maughan T, McDonald A, Essapen S, Leslie M, Falk S, Wilson C, Gollins S, Begum R, Ledermann J, Kadalayil L, Sebag-Montefiore D (2013) Mitomycin or cisplatin 
chemoradiation with or without maintenance chemotherapy for treatment of squamous-cell carcinoma of the anus (ACT II): a randomised, phase 3, open-label, $2 \times 2$ factorial trial. Lancet Oncol 14(6):516-524. https://doi.org/10.1016/S1470-2045(13)70086-X

111. Bazan JG, Koong AC, Kapp DS, Quon A, Graves EE, Loo BW, Chang DT (2013) Metabolic tumor volume predicts disease progression and survival in patients with squamous cell carcinoma of the anal canal. J Nucl Med 54(1):27. https://doi.org/10.2967/ jnumed.112.109470

112. Cotter SE, Grigsby PW, Siegel BA, Dehdashti F, Malyapa RS, Fleshman JW, Birnbaum EH, Wang X, Abbey E, Tan B, Kodner IJ, Hunt SR, Lowney JK, Mutch MG, Dietz DW, Myerson RJ (2006) FDG-PET/CT in the evaluation of anal carcinoma. Int J Radiat Oncol Biol Phys 65(3):720-725. https://doi.org/10.1016/j.ijrobp. 2006.01.009

113. Mistrangelo M, Pelosi E, Bellò M, Ricardi U, Milanesi E, Cassoni P, Baccega M, Filippini C, Racca P, Lesca A, Munoz FH, Fora G, Skanjeti A, Cravero F, Morino M (2012) Role of positron emission tomography-computed tomography in the management of anal cancer. Int J Radiat Oncol Biol Phys 84(1):66-72. https://doi. org/10.1016/j.ijrobp.2011.10.048

114. Nguyen BT, Joon DL, Khoo V, Quong G, Chao M, Wada M, Joon ML, See A, Feigen M, Rykers K, Kai C, Zupan E, Scott A (2008) Assessing the impact of FDG-PET in the management of anal cancer. Radiother Oncol 87(3):376-382. https://doi.org/10. 1016/j.radonc. 2008.04.003

115. Vercellino L, Montravers F, de Parades V, Huchet V, Kerrou K, Bauer P, Touboul E, Talbot J-N (2011) Impact of FDG PET/CT in the staging and the follow-up of anal carcinoma. Int J Colorectal Dis 26(2):201-210. https://doi.org/10.1007/s00384-010-1080-9

116. Winton E, Heriot AG, Ng M, Hicks RJ, Hogg A, Milner A, Leong T, Fay M, MacKay J, Drummond E, Ngan SY (2009) The impact of 18-fluorodeoxyglucose positron emission tomography on the staging, management and outcome of anal cancer. $\mathrm{Br} \mathrm{J}$ Cancer 100(5):693-700. https://doi.org/10.1038/sj.bjc.6604897

117. Deantonio L, Milia ME, Cena T, Sacchetti G, Perotti C, Brambilla M, Turri L, Krengli M (2016) Anal cancer FDG-PET standard uptake value: correlation with tumor characteristics, treatment response and survival. Radiol Med 121(1):54-59. https://doi.org/10. 1007/s11547-015-0562-9

118. Gauthé M, Richard-Molard M, Fayard J, Alberini J-L, Cacheux W, Lièvre A (2017) Prognostic impact of tumour burden assessed by metabolic tumour volume on FDG PET/CT in anal canal cancer. Eur J Nucl Med Mol Imaging 44(1):63-70. https://doi.org/10.1007/ s00259-016-3475-5

119. Aide N, Tainturier L-E, Nganoa C, Houdu B, Kammerer J, Galais M-P, Ciappuccini R, Lasnon C (2020) HYPHYCA: a prospective study in 613 patients conducting a comprehensive analysis for predictive factors of physiological $18 \mathrm{~F}-\mathrm{FDG}$ anal uptake. EJNMMI Res 10(1):28. https://doi.org/10.1186/s13550-020-0615-5

120. Mahmud A, Poon R, Jonker D (2017) PET imaging in anal canal cancer: a systematic review and meta-analysis. Br J Radiol 90(1080):20170370. https://doi.org/10.1259/bjr.20170370

121. Maas M, Tielbeek JAW, Stoker J (2020) Staging of anal cancer: role of MR Imaging. Magn Reson Imaging Clin N Am 28(1):127-140. https://doi.org/10.1016/j.mric.2019.09.005

122. Otto SD, Lee L, Buhr HJ, Frericks B, Höcht S, Kroesen AJ (2009) Staging anal cancer: prospective comparison of transanal endoscopic ultrasound and magnetic resonance imaging. J Gastrointest Surg 13(7):1292-1298. https://doi.org/10.1007/s11605-009-08702

123. Reginelli A, Granata V, Fusco R, Granata F, Rega D, Roberto L, Pellino G, Rotondo A, Selvaggi F, Izzo F, Petrillo A, Grassi R (2017) Diagnostic performance of magnetic resonance imaging and $3 \mathrm{D}$ endoanal ultrasound in detection, staging and assessment post treatment, in anal cancer. Oncotarget 8(14):22980-22990. https:// doi.org/10.18632/oncotarget.14946

124. Catalano OA, Lee SI, Parente C, Cauley C, Furtado FS, Striar R, Soricelli A, Salvatore M, Li Y, Umutlu L, Cañamaque LG, Groshar D, Mahmood U, Blaszkowsky LS, Ryan DP, Clark JW, Wo J, Hong TS, Kunitake H, Bordeianou L, Berger D, Ricciardi R, Rosen B (2020) Improving staging of rectal cancer in the pelvis: the role of PET/MRI. Eur J Nucl Med Mol Imaging. https://doi. org/10.1007/s00259-020-05036- $\mathrm{x}$

125. Rusten E, Rekstad BL, Undseth C, Al-Haidari G, Hanekamp B, Hernes E, Hellebust TP, Malinen E, Guren MG (2017) Target volume delineation of anal cancer based on magnetic resonance imaging or positron emission tomography. Radiat Oncol 12(1):147. https://doi.org/10.1186/s13014-017-0883-Z

126. Myerson RJ, Garofalo MC, El Naqa I, Abrams RA, Apte A, Bosch WR, Das P, Gunderson LL, Hong TS, Kim JJJ, Willett CG, Kachnic LA (2009) Elective clinical target volumes for conformal therapy in anorectal cancer: a radiation therapy oncology group consensus panel contouring atlas. Int J Radiat Oncol Biol Phys 74(3):824-830. https://doi.org/10.1016/j.ijrobp.2008.08.070

127. Ng M, Leong T, Chander S, Chu J, Kneebone A, Carroll S, Wiltshire K, Ngan S, Kachnic L (2012) Australasian gastrointestinal trials group (AGITG) contouring atlas and planning guidelines for intensity-modulated radiotherapy in anal cancer. Int J Radiat Oncol 83(5):1455-1462. https://doi.org/10.1016/j.ijrobp.2011.12.058

128. Jones M, Hruby G, Solomon M, Rutherford N, Martin J (2015) The role of FDG-PET in the initial staging and response assessment of anal cancer: a systematic review and meta-analysis. Ann Surg Oncol 22(11):3574-3581. https://doi.org/10.1245/s10434-015-43919

129. Dapper H, Schiller K, Münch S, Peeken JC, Borm K, Weber W, Combs SE (2019) Have we achieved adequate recommendations for target volume definitions in anal cancer? A PET imaging based patterns of failure analysis in the context of established contouring guidelines. BMC Cancer 19(1):742. https://doi.org/10.1186/ s12885-019-5970-0

130. Saboo SS, Zukotynski K, Shinagare AB, Krajewski KM, Ramaiya N (2013) Anal carcinoma: FDG PET/CT in staging, response evaluation, and follow-up. Abdom Imaging 38(4):728-735. https:// doi.org/10.1007/s00261-012-9958-3

131. Schwarz JK, Siegel BA, Dehdashti F, Myerson RJ, Fleshman JW, Grigsby PW (2008) Tumor response and survival predicted by posttherapy FDG-PET/CT in anal cancer. Int J Radiat Oncol Biol Phys 71(1):180-186. https://doi.org/10.1016/j.ijrobp.2007.09.005

132. Day FL, Link E, Ngan S, Leong T, Moodie K, Lynch C, Michael M, Winton E, Hogg A, Hicks RJ, Heriot A (2011) FDG-PET metabolic response predicts outcomes in anal cancer managed with chemoradiotherapy. Br J Cancer 105(4):498-504. https://doi.org/10.1038/ bjc. 2011.274

133. Marnitz S, Köhler C, Roth C, Füller J, Bischoff A, Wendt T, Schneider A, Budach V (2007) Stage-adjusted chemoradiation in cervical cancer after transperitoneal laparoscopic staging. Strahlenther Onkol 183(9):473-478. https://doi.org/10.1007/s00066-007-16754

134. Marnitz S, Köhler C, Affonso RJ, Schneider A, Chiantera V, Tsounoda A, Vercellino F (2012) Validity of laparoscopic staging to avoid adjuvant chemoradiation following radical surgery in patients with early cervical cancer. Oncology 83(6):346-353. https://doi.org/10. $1159 / 000341659$

135. Gouy S, Morice P, Narducci F, Uzan C, Gilmore J, KolesnikovGauthier H, Querleu D, Haie-Meder C, Leblanc E (2012) Nodalstaging surgery for locally advanced cervical cancer in the era of PET. Lancet Oncol 13(5):e212-e220. https://doi.org/10.1016/ S1470-2045(12)70011-6

136. Leblanc E, Gauthier H, Querleu D, Ferron G, Zerdoud S, Morice P, Uzan C, Lumbroso S, Lecuru F, Bats AS, Ghazzar N, Bannier M, 
Houvenaeghel G, Brenot-Rossi I, Narducci F (2011) Accuracy of 18-Fluoro-2-deoxy-d-glucose positron emission tomography in the pretherapeutic detection of occult para-aortic node involvement in patients with a locally advanced cervical carcinoma. Ann Surg Oncol 18(8):2302-2309. https://doi.org/10.1245/s10434-011-1583-9

137. Marnitz S, Tsunoda AT, Martus P, Vieira M, Affonso Junior RJ, Nunes J, Budach V, Hertel H, Mustea A, Sehouli J, Scharf J-P, Ulrich U, Ebert A, Piwonski I, Kohler C (2020) Surgical versus clinical staging prior to primary chemoradiation in patients with cervical cancer FIGO stages IIB-IVA: oncologic results of a prospective randomized international multicenter (Uterus-11) intergroup study. Int J Gynecol Cancer 30(12):1855-1861. https://doi.org/10.1136/ ijgc-2020-001973

138. Köhler C, Mustea A, Marnitz S, Schneider A, Chiantera V, Ulrich U, Scharf J-P, Martus P, Vieira MA, Tsunoda A (2015) Perioperative morbidity and rate of upstaging after laparoscopic staging for patients with locally advanced cervical cancer: results of a prospective randomized trial. Am J Obstet Gynecol 213(4):503.e1-503.e57. https://doi.org/10.1016/j.ajog.2015.05.026

139. Tsunoda AT, Marnitz S, Soares Nunes J, Mattos de Cunha Andrade CE, Scapulatempo Neto C, Blohmer JU, Herrmann J, Kerr LM, Martus P, Schneider A, Favero G, Köhler C (2017) Incidence of histologically proven pelvic and para-aortic lymph node metastases and rate of upstaging in patients with locally advanced cervical cancer: results of a prospective randomized trial. Oncology 92(4):213-220. https://doi.org/10.1159/000453666

140. Marnitz S, Schram J, Budach V, Sackerer I, Vercellino GF, Sehouli J, Köhler C (2015) Extended field chemoradiation for cervical cancer patients with histologically proven para-aortic lymph node metastases after laparaoscopic lymphadenectomy. Strahlenther Onkol 191(5):421-428. https://doi.org/10.1007/s00066-014$0785-\mathrm{z}$

141. Gouy S, Morice P, Narducci F, Uzan C, Martinez A, Rey A, Bentivegna E, Pautier P, Deandreis D, Querleu D, Haie-Meder C, Leblanc E (2013) Prospective multicenter study evaluating the survival of patients with locally advanced cervical cancer undergoing laparoscopic para-aortic lymphadenectomy before chemoradiotherapy in the era of positron emission tomography imaging. J Clin Oncol 31(24):3026-3033. https://doi.org/10.1200/jco.2012. 47.3520

142. Frumovitz M, Querleu D, Gil-Moreno A, Morice P, Jhingran A, Munsell MF, Macapinlac HA, LeBlanc E, Martinez A, Ramirez PT (2014) Lymphadenectomy in locally advanced cervical cancer study (LiLACS): phase III clinical trial comparing surgical with radiologic staging in patients with stages IB2-IVA cervical cancer. J Minim Invasive Gynecol 21(1):3-8. https://doi.org/10.1016/j. jmig.2013.07.007

143. Lima GM, Matti A, Vara G, Dondi G, Naselli N, De Crescenzo EM, Morganti AG, Perrone AM, De Iaco P, Nanni C, Fanti S (2018) Prognostic value of posttreatment ${ }^{18} \mathrm{~F}$-FDG PET/CT and predictors of metabolic response to therapy in patients with locally advanced cervical cancer treated with concomitant chemoradiation therapy: an analysis of intensity- and volume-based PET parameters. Eur J Nucl Med Mol Imaging 45(12):2139-2146. https://doi. org/10.1007/s00259-018-4077-1

144. Rufini V, Collarino A, Calcagni ML, Meduri GM, Fuoco V, Pasciuto T, Testa AC, Ferrandina G, Gambacorta MA, Campitelli M, Gui B, Zannoni G, Manfredi R, Scambia G, Giordano A (2020) The role of FDG-PET/CT in predicting the histopathological response in locally advanced cervical carcinoma treated by chemoradiotherapy followed by radical surgery: a prospective study. Eur J Nucl Med Mol Imaging 47(5):1228-1238. https://doi.org/10.1007/ s00259-019-04436-y

145. Gupta S, Maheshwari A, Parab P, Mahantshetty U, Hawaldar R, Sastri Chopra S, Kerkar R, Engineer R, Tongaonkar H, Ghosh J, Gulia S, Kumar N, Shylasree TS, Gawade R, Kembhavi Y,
Gaikar M, Menon S, Thakur M, Shrivastava S, Badwe R (2018) Neoadjuvant chemotherapy followed by radical surgery versus concomitant chemotherapy and radiotherapy in patients with stage IB2, IIA, or IIB squamous cervical cancer: a randomized controlled trial. J Clin Oncol 36(16):1548-1555. https://doi.org/10.1200/jco. 2017.75.9985

146. Kenter G, Greggi S, Vergote I, Katsaros D, Kobierski J, Massuger L, van Doorn HC, Landoni F, Velden JVD, Reed NS, Coens C, van Luijk I, Ottevanger PB, Casado A (2019) Results from neoadjuvant chemotherapy followed by surgery compared to chemoradiation for stage Ib2-IIb cervical cancer, EORTC 55994. J Clin Oncol 37(15_suppl):5503-5503. https://doi.org/10.1200/JCO.2019.37. 15_suppl.5503

147. Gee MS, Atri M, Bandos AI, Mannel RS, Gold MA, Lee SI (2017) Identification of distant metastatic disease in uterine cervical and endometrial cancers with FDG PET/CT: analysis from the ACRIN 6671/GOG 0233 multicenter trial. Radiology 287(1):176-184. https://doi.org/10.1148/radiol.2017170963

148. Kidd EA, Spencer CR, Huettner PC, Siegel BA, Dehdashti F, Rader JS, Grigsby PW (2009) Cervical cancer histology and tumor differentiation affect 18F-fluorodeoxyglucose uptake. Cancer 115(15):3548-3554. https://doi.org/10.1002/cncr.24400

149. Zhou Z, Liu X, Hu K, Zhang F (2018) The clinical value of PET and PET/CT in the diagnosis and management of suspected cervical cancer recurrence. Nucl Med Commun 39(2):97-102

150. Leitlinienprogramm Onkologie (2021) S3-Leitlinie Diagnostik und Therapie Zervixkarzinom, Langversion 2.0. https://www. leitlinienprogramm-onkologie.de/fileadmin/user_upload/Downlo ads/Leitlinien/Zervixkarzinom/Version_2/LL_Zervixkarzinom_La ngversion_2.0.pdf. Accessed: mid-January 2021

151. Kratochwil C, Flechsig P, Lindner T, Abderrahim L, Altmann A, Mier W, Adeberg S, Rathke H, Röhrich M, Winter H, Plinkert PK, Marme F, Lang M, Kauczor H-U, Jäger D, Debus J, Haberkorn U, Giesel FL (2019) ${ }^{68}$ Ga-FAPI PET/CTa-FAPI PET/CT: tracer uptake in 28 different kinds of cancer. J Nucl Med 60(6):801. https://doi. org/10.2967/jnumed.119.227967

152. Eiber M, Kroenke M, Wurzer A, Ulbrich L, Jooß L, Maurer T, Horn T, Schiller K, Langbein T, Buschner G, Wester H-J, Weber W (2020) ${ }^{18}$ F-rhPSMA-7 PET for the detection of biochemical recurrence of prostate cancer after radical prostatectomy. J Nucl Med 61(5):696-701. https://doi.org/10.2967/jnumed.119.234914

153. Giesel FL, Knorr K, Spohn F, Will L, Maurer T, Flechsig P, Neels O, Schiller K, Amaral H, Weber WA, Haberkorn U, Schwaiger M, Kratochwil C, Choyke P, Kramer V, Kopka K, Eiber M (2019) Detection efficacy of ${ }^{18} \mathrm{~F}$-PSMA-1007 PET/CT in 251 patients with biochemical recurrence of prostate cancer after radical prostatectomy. J Nucl Med 60(3):362-368. https://doi.org/10.2967/jnumed. 118.212233

154. Rowe SP, Macura KJ, Ciarallo A, Mena E, Blackford A, Nadal R, Antonarakis ES, Eisenberger MA, Carducci MA, Ross AE, Kantoff PW, Holt DP, Dannals RF, Mease RC, Pomper MG, Cho SY (2016) Comparison of prostate-specific membrane antigen-based ${ }^{18} \mathrm{~F}-\mathrm{DCFBC}$ PET/CT to conventional imaging modalities for detection of hormone-naïve and castration-resistant metastatic prostate cancer. J Nucl Med 57(1):46-53. https://doi.org/10.2967/jnumed. 115.163782

155. Kroenke M, Mirzoyan L, Horn T, Peeken JC, Wurzer A, Wester H-J, Makowski M, Weber WA, Eiber M, Rauscher I (2020) Matchedpair comparison of ${ }^{68} \mathrm{Ga}$-PSMA-11 and ${ }^{18} \mathrm{~F}-\mathrm{rhPSMA}-7$ PET/CT in patients with primary and biochemical recurrence of prostate cancer: frequency of non-tumor related uptake and tumor positivity. J Nucl Med. https://doi.org/10.2967/jnumed.120.251447

156. Cappel CC, Dopcke D, Dunst J (2021) PSMA-PET-CT zum primären Staging von Patienten mit fortgeschrittenem Prostatakarzinom. Strahlenther Onkol 197(3):257-260. https://doi.org/10.1007/ s00066-020-01732-7 
157. Hofman MS, Lawrentschuk N, Francis RJ, Tang C, Vela I, Thomas P, Rutherford N, Martin JM, Frydenberg M, Shakher R, Wong L-M, Taubman K, Ting Lee S, Hsiao E, Roach P, Nottage M, Kirkwood I, Hayne D, Link E, Marusic P, Matera A, Herschtal A, Iravani A, Hicks RJ, Williams S, Murphy DG (2020) Prostatespecific membrane antigen PET-CT in patients with high-risk prostate cancer before curative-intent surgery or radiotherapy (proPSMA): a prospective, randomised, multicentre study. Lancet 395(10231):1208-1216. https://doi.org/10.1016/S0140-6736(20) 30314-7

158. Dewes S, Schiller K, Sauter K, Eiber M, Maurer T, Schwaiger M, Gschwend JE, Combs SE, Habl G (2016) Integration of 68GaPSMA-PET imaging in planning of primary definitive radiotherapy in prostate cancer: a retrospective study. Radiat Oncol 11(1):73. https://doi.org/10.1186/s13014-016-0646-2

159. Calais J, Kishan AU, Cao M, Fendler WP, Eiber M, Herrmann K, Ceci F, Reiter RE, Rettig MB, Hegde JV, Shaverdian N, King CR, Steinberg ML, Czernin J, Nickols NG (2018) Potential impact of 68Ga-PSMA-11 PET/CT on the planning of definitive radiation therapy for prostate cancer. J Nucl Med 59(11):1714. https://doi. org/10.2967/jnumed.118.209387

160. Kerkmeijer LGW, Groen VH, Pos FJ, Haustermans K, Monninkhof EM, Smeenk RJ, Kunze-Busch M, de Boer JCJ, van der Voort van Zijp J, van Vulpen M, Draulans C, van den Bergh L, Isebaert S, van der Heide UA (2021) Focal boost to the intraprostatic tumor in external beam radiotherapy for patients with localized prostate cancer: results from the FLAME randomized phase III trial. J Clin Oncol 39(7):787-796. https://doi.org/10.1200/JCO.20. 02873

161. Bettermann AS, Zamboglou C, Kiefer S, Jilg CA, Spohn S, KranzRudolph J, Fassbender TF, Bronsert P, Nicolay NH, Gratzke C, Bock M, Ruf J, Benndorf M, Grosu AL (2019) [68Ga-]PSMA-11 PET/CT and multiparametric MRI for gross tumor volume delineation in a slice by slice analysis with whole mount histopathology as a reference standard-Implications for focal radiotherapy planning in primary prostate cancer. Radiother Oncol 141:214-219. https://doi.org/10.1016/j.radonc.2019.07.005

162. Kostyszyn D, Fechter T, Bartl N, Grosu AL, Gratzke C, Sigle A, Mix M, Ruf J, Fassbender TF, Kiefer S, Bettermann AS, Nicolay NH, Spohn S, Kramer MU, Bronsert P, Guo H, Qiu X, Wang F, Henkenberens C, Werner RA, Baltas D, Meyer PT, Derlin T, Chen M, Zamboglou C (2020) Intraprostatic tumour segmentation on PSMA-PET images in patients with primary prostate cancer with a convolutional neural network. J Nucl Med. https://doi.org/ 10.2967/jnumed.120.254623

163. Zamboglou C, Fassbender TF, Steffan L, Schiller F, Fechter T, Carles M, Kiefer S, Rischke HC, Reichel K, Schmidt-Hegemann N-S, Ilhan H, Chirindel AF, Nicolas G, Henkenberens C, Derlin T, Bronsert P, Mavroidis P, Chen RC, Meyer PT, Ruf J, Grosu AL (2019) Validation of different PSMA-PET/CT-based contouring techniques for intraprostatic tumor definition using histopathology as standard of reference. Radiother Oncol 141:208-213. https://doi. org/10.1016/j.radonc.2019.07.002

164. Zamboglou C, Schiller F, Fechter T, Wieser G, Jilg CA, Chirindel A, Salman N, Drendel V, Werner M, Mix M, Meyer PT, Grosu AL (2016) ${ }^{68}$ Ga-HBED-CC-PSMA PET/CT versus histopathology in primary localized prostate cancer: a voxel-wise comparison. Theranostics 6(10):1619-1628. https://doi.org/10.7150/thno.15344

165. Zamboglou C, Sachpazidis I, Koubar K, Drendel V, Wiehle R, Kirste S, Mix M, Schiller F, Mavroidis P, Meyer PT, Werner M, Grosu AL, Baltas D (2017) Evaluation of intensity modulated radiation therapy dose painting for localized prostate cancer using 68Ga-HBED-CC PSMA-PET/CT: a planning study based on histopathology reference. Radiother Oncol 123(3):472-477. https:// doi.org/10.1016/j.radonc.2017.04.021
166. Beresford MJ, Gillatt D, Benson RJ, Ajithkumar T (2010) A systematic review of the role of imaging before salvage radiotherapy for post-prostatectomy biochemical recurrence. Clin Oncol 22(1):46-55. https://doi.org/10.1016/j.clon.2009.10.015

167. Bottke D, Bartkowiak D, Siegmann A, Thamm R, Böhmer D, Budach V, Wiegel T (2019) Effect of early salvage radiotherapy at PSA $<0.5 \mathrm{ng} / \mathrm{ml}$ and impact of post-SRT PSA nadir in post-prostatectomy recurrent prostate cancer. Prostate Cancer Prostatic Dis 22(2):344-349. https://doi.org/10.1038/s41391-018-0112-3

168. Ploussard G, Fossati N, Wiegel T, D'Amico A, Hofman MS, Gillessen S, Mottet N, Joniau S, Spratt DE (2021) Management of persistently elevated prostate-specific antigen after radical prostatectomy: a systematic review of the literature. Eur Urol Oncol. https://doi.org/10.1016/j.euo.2021.01.001

169. Magnetta MJ, Casalino D, Heller MT (2020) Imaging assessment of local recurrence of prostate cancer after radical prostatectomy. Abdom Radiol 45(12):4073-4083. https://doi.org/10.1007/s00261020-02505-7

170. Roy C, Foudi F, Charton J, Jung M, Lang H, Saussine C, Jacqmin D (2013) Comparative sensitivities of functional MRI sequences in detection of local recurrence of prostate carcinoma after radical prostatectomy or external-beam radiotherapy. AJR Am J Roentgenol 200(4):W361-W368. https://doi.org/10.2214/AJR.12. 9106

171. Calais J, Ceci F, Eiber M, Hope TA, Hofman MS, Rischpler C, Bach-Gansmo T, Nanni C, Savir-Baruch B, Elashoff D, Grogan T, Dahlbom M, Slavik R, Gartmann J, Nguyen K, Lok V, Jadvar H, Kishan AU, Rettig MB, Reiter RE, Fendler WP, Czernin J (2019) ${ }^{18}$ F-fluciclovine PET-CT and ${ }^{68}$ Ga-PSMA-11 PET-CT in patients with early biochemical recurrence after prostatectomy: a prospective, single-centre, single-arm, comparative imaging trial. Lancet Oncol 20(9):1286-1294. https://doi.org/10.1016/S14702045(19)30415-

172. Emmett L, Metser U, Bauman G, Hicks RJ, Weickhardt A, Davis ID, Punwani S, Pond G, Chua S, Ho B, Johnston E, Pouliot F, Scott AM (2019) Prospective, multisite, international comparison of $\langle$ sup $\rangle$ 18 $/$ /sup $\rangle$ F-fluoromethylcholine PET/CT, multiparametric MRI, and 〈sup〉68//sup〉ga-HBED-CC PSMA-11 PET/CT in men with high-risk features and biochemical failure after radical prostatectomy: clinical performance and patient outcomes. J Nucl Med 60(6):794-800. https://doi.org/10.2967/jnumed.118.220103

173. Morigi JJ, Stricker PD, van Leeuwen PJ, Tang R, Ho B, Nguyen Q, Hruby G, Fogarty G, Jagavkar R, Kneebone A, Hickey A, Fanti S, Tarlinton L, Emmett L (2015) Prospective comparison of ${ }^{18} \mathrm{~F}$ fluoromethylcholine versus $\langle$ sup $\rangle 8$ //sup $\rangle$ Ga-PSMA PET/CT in prostate cancer patients who have rising PSA after curative treatment and are being considered for targeted therapy. J Nucl Med 56(8):1185-1190. https://doi.org/10.2967/jnumed.115.160382

174. Miksch J, Bottke D, Krohn T, Thamm R, Bartkowiak D, Solbach C, Bolenz C, Beer M, Wiegel T, Beer AJ, Prasad V (2020) Interobserver variability, detection rate, and lesion patterns of (68)Ga-PSMA-11-PET/CT in early-stage biochemical recurrence of prostate cancer after radical prostatectomy. Eur J Nucl Med Mol Imaging 47(10):2339-2347. https://doi.org/10.1007/s00259-02004718-W

175. Perera M, Papa N, Roberts M, Williams M, Udovicich C, Vela I, Christidis D, Bolton D, Hofman MS, Lawrentschuk N, Murphy DG (2020) Gallium-68 prostate-specific membrane antigen positron emission tomography in advanced prostate cancer-Updated diagnostic utility, sensitivity, specificity, and distribution of prostatespecific membrane antigen-avid lesions: a systematic review and meta-analysis. Eur Urol 77(4):403-417. https://doi.org/10.1016/j. eururo.2019.01.049

176. Sprute K, Kramer V, Koerber SA, Meneses M, Fernandez R, Soza-Ried C, Eiber M, Weber WA, Rauscher I, Rahbar K, Schaefers M, Watabe T, Uemura M, Naka S, Nonomura N, Hatazawa J, 
Schwab C, Schütz V, Hohenfellner M, Holland-Letz T, Debus J, Kratochwil C, Amaral H, Choyke PL, Haberkorn U, Sandoval C, Giesel FL (2021) Diagnostic accuracy of ${ }^{18}$ F-PSMA-1007 PET/CT imaging for lymph node staging of prostate carcinoma in primary and biochemical recurrence. J Nucl Med 62(2):208-213. https:// doi.org/10.2967/jnumed.120.246363

177. Eiber M, Rauscher I, Souvatzoglou M, Maurer T, Schwaiger M, Holzapfel K, Beer AJ (2017) Prospective head-to-head comparison of 11C-choline-PET/MR and 11C-choline-PET/CT for restaging of biochemical recurrent prostate cancer. Eur J Nucl Med Mol Imaging 44(13):2179-2188. https://doi.org/10.1007/s00259-017-3797y

178. Guberina N, Hetkamp P, Ruebben H, Fendler W, Grueneisen J, Suntharalingam S, Kirchner J, Puellen L, Harke N, Radtke JP, Umutlu L, Hadaschik BA, Herrmann K, Forsting M, Wetter A (2020) Whole-body integrated [68Ga]PSMA-11-PET/MR imaging in patients with recurrent prostate cancer: comparison with wholebody PET/CT as the standard of reference. Mol Imaging Biol 22(3):788-796. https://doi.org/10.1007/s11307-019-01424-4

179. Slevin F, Beasley M, Cross W, Scarsbrook A, Murray L, Henry A (2020) Patterns of lymph node failure in patients with recurrent prostate cancer postradical prostatectomy and implications for salvage therapies. Adv Radiat Oncol 5(6):1126-1140. https://doi.org/ 10.1016/j.adro.2020.07.009

180. Schiller K, Stöhrer L, Düsberg M, Borm K, Devecka M, Vogel MME, Tauber R, Heck MM, Rauscher I, Eiber M, Gschwend JE, Duma MN, Combs SE (2021) PSMA-PET/CT-based lymph node atlas for prostate cancer patients recurring after primary treatment: clinical implications for salvage radiation therapy. Eur Urol Oncol 4(1):73-83. https://doi.org/10.1016/j.euo.2020.04.004

181. Valle L, Shabsovich D, de Meerleer G, Maurer T, Murphy DG, Nickols NG, Vapiwala N, Calais J, Kishan AU (2021) Use and impact of positron emission tomography/computed tomography prior to salvage radiation therapy in men with biochemical recurrence after radical prostatectomy: a scoping review. Eur Urol Oncol. https:// doi.org/10.1016/j.euo.2021.01.007

182. Hurmuz P, Onal C, Ozyigit G, Igdem S, Atalar B, Sayan H, Akgun Z, Kurt M, Ozkok HB, Selek U, Oymak E, Tilki B, Guler OC, Mustafayev TZ, Saricanbaz I, Rzazade R, Akyol F (2020) Treatment outcomes of metastasis-directed treatment using 68GaPSMA-PET/CT for oligometastatic or oligorecurrent prostate cancer: Turkish Society for Radiation Oncology group study (TROD 09-002). Strahlenther Onkol 196(11):1034-1043. https://doi.org/ 10.1007/s00066-020-01660-6

183. Bluemel C, Linke F, Herrmann K, Simunovic I, Eiber M, Kestler C, Buck AK, Schirbel A, Bley TA, Wester H-J, Vergho D, Becker A (2016) Impact of 68Ga-PSMA PET/CT on salvage radiotherapy planning in patients with prostate cancer and persisting PSA values or biochemical relapse after prostatectomy. EJNMMI Res 6(1):78. https://doi.org/10.1186/s13550-016-0233-4

184. Habl G, Sauter K, Schiller K, Dewes S, Maurer T, Eiber M, Combs SE (2017) 68Ga-PSMA-PET for radiation treatment planning in prostate cancer recurrences after surgery: Individualized medicine or new standard in salvage treatment. Prostate 77(8):920-927. https://doi.org/10.1002/pros.23347

185. Schmidt-Hegemann N-S, Fendler WP, Ilhan H, Herlemann A, Buchner A, Stief C, Eze C, Rogowski P, Li M, Bartenstein P, Ganswindt U, Belka C (2018) Outcome after PSMA PET/CT based radiotherapy in patients with biochemical persistence or recurrence after radical prostatectomy. Radiat Oncol 13(1):37. https://doi.org/ 10.1186/s13014-018-0983-4

186. Henkenberens C, Oehus AK, Derlin T, Bengel F, Ross TL, Kuczyk MA, Janssen S, Christiansen H, von Klot CAJ (2020) Efficacy of repeated PSMA PET-directed radiotherapy for oligorecurrent prostate cancer after initial curative therapy. Strahlenther
Onkol 196(11):1006-1017. https://doi.org/10.1007/s00066-02001629-5

187. Janikova A, Bolcak K, Pavlik T, Mayer J, Kral Z (2008) Value of $\left[{ }^{18} \mathrm{~F}\right]$ Fluorodeoxyglucose positron emission tomography in the management of follicular lymphoma: the end of a dilemma? Clin Lymphoma Myeloma 8(5):287-293. https://doi.org/10.3816/CLM. 2008.n.040

188. Scott AM, Gunawardana DH, Wong J, Kirkwood I, Hicks RJ, Ho Shon I, Ramshaw JE, Robins P (2009) Positron emission tomography changes management, improves prognostic stratification and is superior to gallium scintigraphy in patients with low-grade lymphoma: results of a multicentre prospective study. Eur J Nucl Med Mol Imaging 36(3):347-353. https://doi.org/10.1007/s00259-0080958-z

189. Wirth A, Foo M, Seymour JF, MacManus MP, Hicks RJ (2008) Impact of $[18 \mathrm{~F}]$ fluorodeoxyglucose positron emission tomography on staging and management of early-stage follicular non-Hodgkin lymphoma. Int J Radiat Oncol Biol Phys 71(1):213-219. https:// doi.org/10.1016/j.ijrobp.2007.09.051

190. Brady JL, Binkley MS, Hajj C, Chelius M, Chau K, Balogh A, Levis M, Filippi AR, Jones M, Mac Manus M, Wirth A, Oguchi M, Vistisen AK, Andraos TY, Ng AK, Aleman BMP, Choi SH, Kirova Y, Hardy S, Reinartz G, Eich HT, Bratman SV, Constine LS, Suh C-O, Dabaja B, El-Galaly TC, Hodgson DC, Ricardi U, Yahalom J, Hoppe RT, Mikhaeel NG (2019) Definitive radiotherapy for localized follicular lymphoma staged by 18F-FDG PET-CT: a collaborative study by ILROG. Blood 133(3):237-245. https:// doi.org/10.1182/blood-2018-04-843540

191. MacManus M, Fisher R, Roos D, O'Brien P, Macann A, Davis S, Tsang R, Christie D, McClure B, Joseph D, Jayamohan J, Seymour JF (2018) Randomized trial of systemic therapy after involved-field radiotherapy in patients with early-stage follicular lymphoma: TROG 99.03. J Clin Oncol 36(29):2918-2925. https:// doi.org/10.1200/jco.2018.77.9892

192. Figura N, Flampouri S, Mendenhall NP, Morris CG, McCook B, Ozdemir S, Slayton W, Sandler E, Hoppe BS (2017) Importance of baseline PET/CT imaging on radiation field design and relapse rates in patients with Hodgkin lymphoma. Adv Radiat Oncol 2(2):197-203. https://doi.org/10.1016/j.adro.2017.01.006

193. MacManus M, Nestle U, Rosenzweig KE, Carrio I, Messa C, Belohlavek O, Danna M, Inoue T, Deniaud-Alexandre E, Schipani S, Watanabe N, Dondi M, Jeremic B (2009) Use of PET and PET/CT for radiation therapy planning: IAEA expert report 2006-2007. Radiother Oncol 91(1):85-94. https://doi.org/10.1016/j.radonc.2008. 11.008

194. Terezakis SA, Schoder H, Kowalski A, McCann P, Schmidtlein C, Gonen M, Kirov A, Lovie S, Yahalom J (2010) A prospective study of 18FDG-PET with CT scan co-registration for radiation treatment planning of lymphoma and hematologic malignancies. Int $\mathrm{J}$ Radiat Oncol Biol Phys 78(3):550. https://doi.org/10.1016/j.ijrobp. 2010.07.1284

195. Weiler-Sagie M, Bushelev O, Epelbaum R, Dann EJ, Haim N, Avivi I, Ben-Barak A, Ben-Arie Y, Bar-Shalom R, Israel O (2010) ${ }^{18}$ F-FDG avidity in lymphoma readdressed: a study of 766 patients. J Nucl Med 51(1):25. https://doi.org/10.2967/jnumed.109.067892

196. Yeoh K-W, Mikhaeel NG (2013) Are we ready for positron emission tomography/computed tomography-based target volume definition in lymphoma radiation therapy? Int J Radiat Oncol Biol Phys 85(1):14-20. https://doi.org/10.1016/j.ijrobp.2012.02.023

197. Girinsky T, Aupérin A, Ribrag V, Elleuch M, Fermé C, Bonniaud G, Ruelle C, Alberini J-L, Celebic A, Edeline V (2014) Role of FDG-PET in the implementation of involved-node radiation therapy for Hodgkin lymphoma patients. Int J Radiat Oncol Biol Phys 89(5):1047-1052. https://doi.org/10.1016/j.ijrobp.2014.04.026

198. Hutchings M, Loft A, Hansen M, Berthelsen AK, Specht L (2007) Clinical impact of FDG-PET/CT in the planning of radiotherapy for 
early-stage Hodgkin lymphoma. Eur J Haematol 78(3):206-212. https://doi.org/10.1111/j.1600-0609.2006.00802.x

199. Illidge T, Specht L, Yahalom J, Aleman B, Berthelsen AK, Constine L, Dabaja B, Dharmarajan K, Ng A, Ricardi U, Wirth A (2014) Modern radiation therapy for nodal non-Hodgkin lymphoma-Target definition and dose guidelines from the International Lymphoma Radiation Oncology Group. Int J Radiat Oncol Biol Phys 89(1):49-58. https://doi.org/10.1016/j.ijrobp.2014.01. 006

200. Specht L, Yahalom J, Illidge T, Berthelsen AK, Constine LS, Eich HT, Girinsky T, Hoppe RT, Mauch P, Mikhaeel NG, Ng A (2014) Modern radiation therapy for Hodgkin lymphoma: field and dose guidelines from the International Lymphoma Radiation Oncology Group (ILROG). Int J Radiat Oncol Biol Phys 89(4):854-862. https://doi.org/10.1016/j.ijrobp.2013.05.005

201. Yahalom J, Illidge T, Specht L, Hoppe RT, Li Y-X, Tsang R, Wirth A (2015) Modern radiation therapy for extranodal lymphomas: field and dose guidelines from the International Lymphoma Radiation Oncology Group. Int J Radiat Oncol Biol Phys 92(1):11-31. https://doi.org/10.1016/j.ijrobp.2015.01.009

202. Girinsky T, van der Maazen R, Specht L, Aleman B, Poortmans P, Lievens Y, Meijnders P, Ghalibafian M, Meerwaldt J, Noordijk E (2006) Involved-node radiotherapy (INRT) in patients with early Hodgkin lymphoma: concepts and guidelines. Radiother Oncol 79(3):270-277. https://doi.org/10.1016/j.radonc.2006.05.015

203. Barrington SF, Mikhaeel NG, Kostakoglu L, Meignan M, Hutchings M, Müeller SP, Schwartz LH, Zucca E, Fisher RI, Trotman J, Hoekstra OS, Hicks RJ, O’Doherty MJ, Hustinx R, Biggi A, Cheson BD (2014) Role of imaging in the staging and response assessment of lymphoma: consensus of the International Conference on Malignant Lymphomas Imaging Working Group. J Clin Oncol 32(27):3048-3058. https://doi.org/10.1200/JCO.2013.53.5229

204. Johnson P, Federico M, Kirkwood A, Fosså A, Berkahn L, Carella A, d'Amore F, Enblad G, Franceschetto A, Fulham M, Luminari S, O’Doherty M, Patrick P, Roberts T, Sidra G, Stevens L, Smith P, Trotman J, Viney Z, Radford J, Barrington S (2016) Adapted Treatment guided by interim PET-CT scan in advanced Hodgkin's lymphoma. N Engl J Med 374(25):2419-2429. https://doi.org/10. 1056/NEJMoa1510093

205. Radford J, Illidge T, Counsell N, Hancock B, Pettengell R, Johnson P, Wimperis J, Culligan D, Popova B, Smith P, McMillan A, Brownell A, Kruger A, Lister A, Hoskin P, O’Doherty M, Barrington S (2015) Results of a trial of PET-directed therapy for earlystage Hodgkin's lymphoma. N Engl J Med 372(17):1598-1607. https://doi.org/10.1056/NEJMoa1408648

206. André MPE, Girinsky T, Federico M, Reman O, Fortpied C, Gotti M, Casasnovas O, Brice P, van der Maazen R, Re A, Edeline V, Fermé C, van Imhoff G, Merli F, Bouabdallah R, Sebban C, Specht L, Stamatoullas A, Delarue R, Fiaccadori V, Bellei M, Raveloarivahy T, Versari A, Hutchings M, Meignan M, Raemaekers J (2017) Early positron emission tomography responseadapted treatment in stage I and II Hodgkin lymphoma: final results of the randomized EORTC/LYSA/FIL H10 trial. J Clin Oncol 35(16):1786-1794. https://doi.org/10.1200/jco.2016.68.6394

207. Fuchs M, Goergen H, Kobe C, Kuhnert G, Lohri A, Greil R, Sasse S, Topp MS, Schäfer E, Hertenstein B, Soekler M, Vogelhuber M, Zijlstra JM, Keller UB, Krause SW, Wilhelm M, Maschmeyer G, Thiemer J, Dührsen U, Meissner J, Viardot A, Eich H, Baues C, Diehl V, Rosenwald A, von Tresckow B, Dietlein M, Borchmann P, Engert A (2019) Positron emission tomography-guided treatment in early-stage favorable Hodgkin lymphoma: final results of the international, randomized phase III HD16 trial by the German Hodgkin study group. J Clin Oncol 37(31):2835-2845. https://doi.org/10.1200/jco.19.00964

208. Raemaekers JM, André MP, Federico M, Girinsky T, Oumedaly R, Brusamolino E, Brice P, Fermé C, van der Maazen R, Gotti M,
Bouabdallah R, Sebban CJ, Lievens Y, Re A, Stamatoullas A, Morschhauser F, Lugtenburg PJ, Abruzzese E, Olivier P, Casasnovas RO, van Imhoff G, Raveloarivahy T, Bellei M, van der Borght T, Bardet S, Versari A, Hutchings M, Meignan M, Fortpied C (2014) Omitting radiotherapy in early positron emission tomography-negative stage I/II Hodgkin lymphoma is associated with an increased risk of early relapse: clinical results of the preplanned interim analysis of the randomized EORTC/LYSA/FIL H10 trial. J Clin Oncol 32(12):1188-1194. https://doi.org/10.1200/jco.2013.51.9298

209. van den Bosch S, Doornaert PAH, Dijkema T, Zwijnenburg EM, Verhoef LCG, Hoeben BAW, Kasperts N, Smid EJ, Terhaard CHJ, Kaanders JHAM (2020) FDG-PET/CT-based treatment planning for definitive (chemo)radiotherapy in patients with head and neck squamous cell carcinoma improves regional control and survival. Radiother Oncol 142:107-114. https://doi.org/10.1016/j.radonc. 2019.07.025

210. Konert T, Vogel W, MacManus MP, Nestle U, Belderbos J, Grégoire V, Thorwarth D, Fidarova E, Paez D, Chiti A, Hanna GG (2015) PET/CT imaging for target volume delineation in curative intent radiotherapy of non-small cell lung cancer: IAEA consensus report 2014. Radiother Oncol 116(1):27-34. https://doi.org/10. 1016/j.radonc.2015.03.014

211. Specht L, Berthelsen AK (2018) PET/CT in radiation therapy planning. Semin Nucl Med 48(1):67-75. https://doi.org/10.1053/j. semnuclmed.2017.09.006

212. Thorwarth D (2015) Functional imaging for radiotherapy treatment planning: current status and future directions-A review. Br J Radiol 88(1051):20150056. https://doi.org/10.1259/bjr.20150056

213. Zwirner K, Thorwarth D, Winter RM, Welz S, Weiss J, Schwenzer NF, Schmidt H, la Fougère C, Nikolaou K, Zips D, Gatidis S (2018) Voxel-wise correlation of functional imaging parameters in HNSCC patients receiving PET/MRI in an irradiation setup. Strahlenther Onkol 194(8):719-726. https://doi.org/10.1007/ s00066-018-1292-4

214. De Ruysscher D, Mark Lodge M, Jones B, Brada M, Munro A, Jefferson T, Pijls-Johannesma M (2012) Charged particles in radiotherapy: a 5-year update of a systematic review. Radiother Oncol 103(1):5-7. https://doi.org/10.1016/j.radonc.2012.01.003

215. Mac Manus MP, Everitt S, Bayne M, Ball D, Plumridge N, Binns D, Herschtal A, Cruickshank D, Bressel M, Hicks RJ (2013) The use of fused PET/CT images for patient selection and radical radiotherapy target volume definition in patients with non-small cell lung cancer: results of a prospective study with mature survival data. Radiother Oncol 106(3):292-298. https://doi.org/10.1016/j.radonc. 2012.12.018

216. Taeubert L, Berker Y, Beuthien-Baumann B, Hoffmann AL, Troost EGC, Kachelrieß M, Gillmann C (2020) CT-based attenuation correction of whole-body radiotherapy treatment positioning devices in PET/MRI hybrid imaging. Phys Med Biol 65(23):23NT02. https://doi.org/10.1088/1361-6560/abb7c3

217. Thorwarth D, Beyer T, Boellaard R, De Ruysscher D, Grgic A, Lee JA, Pietrzyk U, Sattler B, Schaefer A, van Elmpt W, Vogel W, Oyen WJG, Nestle U (2012) Integration of FDG-PET/CT into external beam radiation therapy planning. Nuklearmedizin 51(04):140-153

218. Winter RM, Leibfarth S, Schmidt H, Zwirner K, Mönnich D, Welz S, Schwenzer NF, la Fougère C, Nikolaou K, Gatidis S, Zips D, Thorwarth D (2018) Assessment of image quality of a radiotherapy-specific hardware solution for PET/MRI in head and neck cancer patients. Radiother Oncol 128(3):485-491. https://doi. org/10.1016/j.radonc.2018.04.018

219. Boellaard R, Delgado-Bolton R, Oyen WJG, Giammarile F, Tatsch K, Eschner W, Verzijlbergen FJ, Barrington SF, Pike LC, Weber WA, Stroobants S, Delbeke D, Donohoe KJ, Holbrook S, Graham MM, Testanera G, Hoekstra OS, Zijlstra J, Visser E, Hoekstra CJ, Pruim J, Willemsen A, Arends B, Kotzerke J, Bockisch A, 
Beyer T, Chiti A, Krause BJ (2015) FDG PET/CT: EANM procedure guidelines for tumour imaging: version 2.0. Eur J Nucl Med Mol Imaging 42(2):328-354. https://doi.org/10.1007/s00259-0142961-x

220. Boellaard R, Oyen WJ, Hoekstra CJ, Hoekstra OS, Visser EP, Willemsen AT, Arends B, Verzijlbergen FJ, Zijlstra J, Paans AM, Comans EF, Pruim J (2008) The Netherlands protocol for standardisation and quantification of FDG whole body PET studies in multicentre trials. Eur J Nucl Med Mol Imaging 35(12):2320-2333. https://doi.org/10.1007/s00259-008-0874-2

221. Berthon B, Evans M, Marshall C, Palaniappan N, Cole N, Jayaprakasam V, Rackley T, Spezi E (2017) Head and neck target delineation using a novel PET automatic segmentation algorithm. Radiother Oncol 122(2):242-247. https://doi.org/10.1016/j.radonc.2016. 12.008

222. Leibfarth S, Eckert F, Welz S, Siegel C, Schmidt H, Schwenzer N, Zips D, Thorwarth D (2015) Automatic delineation of tumor volumes by co-segmentation of combined PET/MR data. Phys Med Biol 60(14):5399-5412. https://doi.org/10.1088/0031-9155/60/14/ 5399

223. Shepherd T, Teras M, Beichel RR, Boellaard R, Bruynooghe M, Dicken V, Gooding MJ, Julyan PJ, Lee JA, Lefevre S, Mix M, Naranjo V, Wu X, Zaidi H, Zeng Z, Minn H (2012) Comparative study with new accuracy metrics for target volume contouring in PET image guided radiation therapy. IEEE Trans Med Imaging 31(11):2006-2024. https://doi.org/10.1109/TMI.2012.2202322

224. Gillies RJ, Kinahan PE, Hricak H (2015) Radiomics: images are more than pictures, they are data. Radiology 278(2):563-577. https://doi.org/10.1148/radiol.2015151169

225. Lambin P, Rios-Velazquez E, Leijenaar R, Carvalho S, van Stiphout RGPM, Granton P, Zegers CML, Gillies R, Boellard R, Dekker A, Aerts HJWL (2012) Radiomics: extracting more information from medical images using advanced feature analysis. Eur $\mathrm{J}$ Cancer 48(4):441-446. https://doi.org/10.1016/j.ejca.2011.11.036

226. Cook GJR, Azad G, Owczarczyk K, Siddique M, Goh V (2018) Challenges and promises of PET radiomics. Int J Radiat Oncol Biol Phys 102(4):1083-1089. https://doi.org/10.1016/j.ijrobp.2017. 12.268

227. Feng Q, Liang J, Wang L, Niu J, Ge X, Pang P, Ding Z (2020) Radiomics analysis and correlation with metabolic parameters in nasopharyngeal carcinoma based on PET/MR imaging. Front Oncol 10:1619

228. Hatt M, Tixier F, Visvikis D, Cheze Le Rest C (2017) Radiomics in PET/CT: more than meets the eye? J Nucl Med 58(3):365. https:// doi.org/10.2967/jnumed.116.184655

229. Lee JW, Lee SM (2018) Radiomics in oncological PET/CT: clinical applications. Nucl Med Mol Imaging 52(3):170-189. https:// doi.org/10.1007/s13139-017-0500-y

230. Lu W, Chen W (2016) Positron emission tomography/computerized tomography for tumor response assessment-A review of clinical practices and radiomics studies. Transl Cancer Res 5(4):364-370. https://doi.org/10.21037/tcr.2016.07.12

231. Song J, Yin Y, Wang H, Chang Z, Liu Z, Cui L (2020) A review of original articles published in the emerging field of radiomics. Eur $\mathbf{J}$ Radiol 127:108991. https://doi.org/10.1016/j.ejrad.2020.108991

232. Ha S, Choi H, Paeng JC, Cheon GJ (2019) Radiomics in oncological PET/CT: a methodological overview. Nucl Med Mol Imaging 53(1):14-29. https://doi.org/10.1007/s13139-019-00571-4

233. Traverso A, Wee L, Dekker A, Gillies R (2018) Repeatability and reproducibility of radiomic features: a systematic review. Int J Radiat Oncol Biol Phys 102(4):1143-1158. https://doi.org/10.1016/j. ijrobp.2018.05.053

234. Carré A, Klausner G, Edjlali M, Lerousseau M, Briend-Diop J, Sun R, Ammari S, Reuzé S, Alvarez Andres E, Estienne T, Niyoteka S, Battistella E, Vakalopoulou M, Dhermain F, Paragios N, Deutsch E, Oppenheim C, Pallud J, Robert C (2020) Standardiza- tion of brain MR images across machines and protocols: bridging the gap for MRI-based radiomics. Sci Rep 10(1):12340. https://doi. org/10.1038/s41598-020-69298-z

235. Depeursinge A, Andrearczyk V, Whybra P, van Griethuysen J, Müller H, Schaer R, Vallières M, Zwanenburg A (2020) Standardised convolutional filtering for radiomics (arXiv:2006.05470 [cs.CV])

236. Zwanenburg A (2019) Radiomics in nuclear medicine: robustness, reproducibility, standardization, and how to avoid data analysis traps and replication crisis. Eur J Nucl Med Mol Imaging 46(13):2638-2655. https://doi.org/10.1007/s00259-019-04391-8

237. Zwanenburg A, Vallières M, Abdalah MA, Aerts HJWL, Andrearczyk V, Apte A, Ashrafinia S, Bakas S, Beukinga RJ, Boellaard R, Bogowicz M, Boldrini L, Buvat I, Cook GJR, Davatzikos C, Depeursinge A, Desseroit M-C, Dinapoli N, Dinh CV, Echegaray S, El Naqa I, Fedorov AY, Gatta R, Gillies RJ, Goh V, Götz M, Guckenberger M, Ha SM, Hatt M, Isensee F, Lambin P, Leger S, Leijenaar RTH, Lenkowicz J, Lippert F, Losnegård A, MaierHein KH, Morin O, Müller H, Napel S, Nioche C, Orlhac F, Pati S, Pfaehler EAG, Rahmim A, Rao AUK, Scherer J, Siddique MM, Sijtsema NM, Socarras Fernandez J, Spezi E, Steenbakkers RJHM, Tanadini-Lang S, Thorwarth D, Troost EGC, Upadhaya T, Valentini V, van Dijk LV, van Griethuysen J, van Velden FHP, Whybra P, Richter C, Löck S (2020) The image biomarker standardization initiative: standardized quantitative radiomics for high-throughput image-based phenotyping. Radiology 295(2):328-338. https://doi. org/10.1148/radiol.2020191145

238. Nicora G, Vitali F, Dagliati A, Geifman N, Bellazzi R (2020) Integrated multi-omics analyses in oncology: a review of machine learning methods and tools. Front Oncol. https://doi.org/10.3389/ fonc. 2020.01030

239. Sharma P, Mukherjee A (2016) Newer positron emission tomography radiopharmaceuticals for radiotherapy planning: an overview. Ann Transl Med 4(3):53-53. https://doi.org/10.3978/j.issn.23055839.2016.01.26

240. Buck AK, Herrmann K, Shen C, Dechow T, Schwaiger M, Wester H-J (2009) Molecular imaging of proliferation in vivo: Positron emission tomography with $[18 \mathrm{~F}]$ fluorothymidine. Methods 48(2):205-215. https://doi.org/10.1016/j.ymeth.2009.03.009

241. Han D, Yu J, Yu Y, Zhang G, Zhong X, Lu J, Yin Y, Fu Z, Mu D, Zhang B, He W, Huo Z, Liu X, Kong L, Zhao S, Sun X (2010) Comparison of $18 \mathrm{~F}$-fluorothymidine and $18 \mathrm{~F}$-fluorodeoxyglucose $\mathrm{PET} / \mathrm{CT}$ in delineating gross tumor volume by optimal threshold in patients with squamous cell carcinoma of thoracic esophagus. Int J Radiat Oncol Biol Phys 76(4):1235-1241. https://doi.org/10.1016/ j.ijrobp.2009.07.1681

242. Liu J, Li C, Hu M, Lu J, Shi X, Xing L, Sun X, Fu Z, Yu J, Meng X (2015) Exploring spatial overlap of high-uptake regions derived from dual tracer positron emission tomography-computer tomography imaging using $18 \mathrm{~F}$-fluorodeoxyglucose and $18 \mathrm{~F}-$ fluorodeoxythymidine in nonsmall cell lung cancer patients: a prospective pilot study. Medicine 94(17):e678-e678. https://doi.org/10. 1097/MD.0000000000000678

243. Loktev A, Lindner T, Mier W, Debus J, Altmann A, Jäger D, Giesel F, Kratochwil C, Barthe P, Roumestand C, Haberkorn U (2018) A tumor-imaging method targeting cancer-associated fibroblasts. J Nucl Med 59(9):1423. https://doi.org/10.2967/jnumed. 118.210435

244. Lindner T, Loktev A, Altmann A, Giesel F, Kratochwil C, Debus J, Jäger D, Mier W, Haberkorn U (2018) Development of quinolinebased theranostic ligands for the targeting of fibroblast activation protein. J Nucl Med 59(9):1415. https://doi.org/10.2967/jnumed. 118.210443

245. Syed M, Flechsig P, Liermann J, Windisch P, Haberkorn U, Debus J, Adeberg S (2019) Fibroblast activation protein (FAPI) specific PET for advanced target volume delineation in head and neck cancer. 
Int J Radiat Oncol Biol Phys 105(1):E383. https://doi.org/10.1016/ j.ijrobp.2019.06.1645

246. Giesel FL, Adeberg S, Syed M, Lindner T, Jiménez-Franco LD, Mavriopoulou E, Staudinger F, Tonndorf-Martini E, Regnery S, Rieken S, El Shafie R, Röhrich M, Flechsig P, Kluge A, Altmann A, Debus J, Haberkorn U, Kratochwil C (2021) FAPI-74 PET/CT using either ${ }^{18} \mathrm{~F}$-AlF or cold-kit ${ }^{68} \mathrm{Ga}$ labeling: biodistribution, radiation dosimetry, and tumor delineation in lung cancer patients. J Nucl Med 62(2):201. https://doi.org/10.2967/jnumed. 120.245084

247. Windisch P, Zwahlen DR, Koerber SA, Giesel FL, Debus J, Haberkorn U, Adeberg S (2020) Clinical results of fibroblast activation protein (FAP) specific PET and implications for radiotherapy planning: systematic review. Cancers 12(9):2629. https:// doi.org/10.3390/cancers12092629

248. Bensch F, van der Veen EL, Lub-de Hooge MN, Jorritsma-Smit A, Boellaard R, Kok IC, Oosting SF, Schröder CP, Hiltermann TJN, van der Wekken AJ, Groen HJM, Kwee TC, Elias SG, Gietema JA, Bohorquez SS, de Crespigny A, Williams SP, Mancao C, Brouwers AH, Fine BM, de Vries EGE (2018) (89)Zr-atezolizumab imaging as a non-invasive approach to assess clinical response to PD-L1 blockade in cancer. Nat Med 24(12):1852-1858. https://doi.org/10. 1038/s41591-018-0255-8

249. Sanchez-Vega F, Hechtman JF, Castel P, Ku GY, Tuvy Y, Won H, Fong CJ, Bouvier N, Nanjangud GJ, Soong J, Vakiani E, Schattner M, Kelsen DP, Lefkowitz RA, Brown K, Lacouture ME, Capanu M, Mattar M, Qeriqi B, Cecchi F, Tian Y, Hembrough T, Nagy RJ, Lanman RB, Larson SM, Pandit-Taskar N, Schöder H, Iacobuzio-Donahue CA, Ilson DH, Weber WA, Berger MF, de Stanchina E, Taylor BS, Lewis JS, Solit DB, Carrasquillo JA, Scaltriti M, Schultz N, Janjigian YY (2019) EGFR and MET amplifications determine response to HER2 inhibition in ERBB2amplified esophagogastric cancer. Cancer Discov 9(2):199-209. https://doi.org/10.1158/2159-8290.Cd-18-0598

250. Lohrmann C, O'Reilly EM, O’Donoghue JA, Pandit-Taskar N, Carrasquillo JA, Lyashchenko SK, Ruan S, Teng R, Scholz W, Maffuid PW, Lewis JS, Weber WA (2019) Retooling a blood-based Biomarker: phase I assessment of the high-affinity CA19-9 antibody HuMab-5B1 for Immuno-PET imaging of pancreatic cancer. Clin Cancer Res 25(23):7014-7023. https://doi.org/10.1158/10780432.Ccr-18-3667

251. Badawi RD, Shi H, Hu P, Chen S, Xu T, Price PM, Ding Y, Spencer BA, Nardo L, Liu W, Bao J, Jones T, Li H, Cherry SR (2019) First human imaging studies with the EXPLORER totalbody PET scanner. J Nucl Med 60(3):299-303. https://doi.org/10. 2967/jnumed.119.226498

252. Welz S, Mönnich D, Pfannenberg C, Nikolaou K, Reimold M, La Fougère C, Reischl G, Mauz P-S, Paulsen F, Alber M, Belka C, Zips D, Thorwarth D (2017) Prognostic value of dynamic hypoxia PET in head and neck cancer: results from a planned interim analysis of a randomized phase II hypoxia-image guided dose escalation trial. Radiother Oncol 124(3):526-532. https://doi.org/10.1016/j. radonc.2017.04.004

253. Zschaeck S, Löck S, Hofheinz F, Zips D, Saksø Mortensen L, Zöphel K, Troost EGC, Boeke S, Saksø M, Mönnich D, Seidlitz A, Johansen J, Skripcak T, Gregoire V, Overgaard J, Baumann M, Krause M (2020) Individual patient data meta-analysis of FMISO and FAZA hypoxia PET scans from head and neck cancer patients undergoing definitive radio-chemotherapy. Radiother Oncol 149:189-196. https://doi.org/10.1016/j.radonc.2020.05.022

254. Thorwarth D, Welz S, Monnich D, Pfannenberg C, Nikolaou K, Reimold M, La Fougere C, Reischl G, Mauz PS, Paulsen F, Alber M, Belka C, Zips D (2019) Prospective evaluation of a tumor control probability model based on dynamic F-18-FMISO PET for head and neck cancer radiotherapy. J Nucl Med 60(12):1698-1704. https://doi.org/10.2967/jnumed.119.227744

255. Grkovski M, Lee NY, Schöder H, Carlin SD, Beattie BJ, Riaz N, Leeman JE, O'Donoghue JA, Humm JL (2017) Monitoring early response to chemoradiotherapy with 18F-FMISO dynamic PET in head and neck cancer. Eur J Nucl Med Mol Imaging 44(10): 1682-1691. https://doi.org/10.1007/s00259-017-3720-6

256. Wiedenmann N, Bunea H, Rischke HC, Bunea A, Majerus L, Bielak L, Protopopov A, Ludwig U, Büchert M, Stoykow C, Nicolay NH, Weber WA, Mix M, Meyer PT, Hennig J, Bock M, Grosu AL (2018) Effect of radiochemotherapy on T2* MRI in HNSCC and its relation to FMISO PET derived hypoxia and FDG PET. Radiat Oncol 13(1):159. https://doi.org/10.1186/s13014-0181103-1

257. Lee N, Schoder H, Beattie B, Lanning R, Riaz N, McBride S, Katabi N, Li D, Yarusi B, Chan S, Mitrani L, Zhang Z, Pfister DG, Sherman E, Baxi S, Boyle J, Morris LGT, Ganly I, Wong R, Humm J (2016) Strategy of using Intratreatment hypoxia imaging to selectively and safely guide radiation dose de-escalation concurrent with chemotherapy for locoregionally advanced human papillomavirus-related oropharyngeal carcinoma. Int J Radiat Oncol Biol Phys 96(1):9-17. https://doi.org/10.1016/j.ijrobp.2016.04. 027

258. van Elmpt W, De Ruysscher D, van der Salm A, Lakeman A, van der Stoep J, Emans D, Damen E, Öllers M, Sonke J-J, Belderbos J (2012) The PET-boost randomised phase II dose-escalation trial in non-small cell lung cancer. Radiother Oncol 104(1):67-71. https:// doi.org/10.1016/j.radonc.2012.03.005

259. van Diessen J, De Ruysscher D, Sonke J-J, Damen E, Sikorska K, Reymen B, van Elmpt W, Westman G, Fredberg Persson G, Dieleman E, Bjorkestrand H, Faivre-Finn C, Belderbos J (2019) The acute and late toxicity results of a randomized phase II dose-escalation trial in non-small cell lung cancer (PET-boost trial). Radiother Oncol 131:166-173. https://doi.org/10.1016/j.radonc.2018.09.019

260. Hellwig D Hope for new developments in the reimbursement of oncological PET/CT in Germany. Nuklearmedizin 60:205-208. https://doi.org/10.1055/a-1429-3039 


\section{Affiliations}

Constantin Lapa ${ }^{1}$ Ursula Nestle $2,3,4 \cdot$ Nathalie L. Albert ${ }^{5} \cdot$ Christian Baues $^{6} \cdot$ Ambros Beer $^{7}$.

Andreas Buck $^{8}$. Volker Budach ${ }^{9}$ Rebecca Bütof ${ }^{10,11}$ • Stephanie E. Combs ${ }^{12,13,14}$ - Thorsten Derlin ${ }^{15}$.

Matthias Eiber ${ }^{16}$. Wolfgang P. Fendler ${ }^{17}$. Christian Furth ${ }^{18}$. Cihan Gani ${ }^{19,20}$ • Eleni Gkika ${ }^{2}$ Anca-L. Grosu ${ }^{2,3}$.

Christoph Henkenberens ${ }^{21}$ - Harun Ilhan ${ }^{5}$. Steffen Löck ${ }^{10,11}$ - Simone Marnitz-Schulze ${ }^{6}$ Matthias Miederer ${ }^{22}$.

Michael Mix ${ }^{23}$ - Nils H. Nicolay ${ }^{2,3}$ • Maximilian Niyazi ${ }^{5,12}$ • Christoph Pöttgen ${ }^{24}$. Claus M. Rödel ${ }^{25,26}$.

Imke Schatka ${ }^{18}$. Sarah M. Schwarzenboeck ${ }^{27}$ - Andrei S. Todica ${ }^{5}$. Wolfgang Weber ${ }^{16}$. Simone Wegen ${ }^{6}$

Thomas Wiegel ${ }^{28}$. Constantinos Zamboglou ${ }^{2,3}$. Daniel Zips ${ }^{19,20}$ - Klaus Zöphel 11,29,30,31,32 . Sebastian Zschaeck ${ }^{33}$.

Daniela Thorwarth ${ }^{19,34}$ - Esther G. C. Troost ${ }^{10,11,29,30,35}$ (D) - Arbeitsgemeinschaft Nuklearmedizin und

Strahlentherapie der DEGRO und DGN

1 Nuclear Medicine, Medical Faculty, University of Augsburg, Augsburg, Germany

2 Department of Radiation Oncology, Faculty of Medicine, University Medical Center Freiburg, Freiburg, Germany

3 German Cancer Consortium (DKTK), Partner Site Freiburg, Freiburg, Germany

4 Department of Radiation Oncology, Kliniken Maria Hilf, Mönchengladbach, Germany

5 Department of Nuclear Medicine, University Hospital, LMU Munich, Munich, Germany

6 Department of Radiation Oncology, Cyberknife and Radiotherapy, Medical Faculty, University Hospital Cologne, Cologne, Germany

7 Department of Nuclear Medicine, Ulm University Hospital, Ulm, Germany

8 Department of Nuclear Medicine, University Hospital Würzburg, Würzburg, Germany

9 Department of Radiation Oncology, Charité Universitätsmedizin Berlin, Campus Virchow-Klinikum, Berlin, Germany

10 Department of Radiotherapy and Radiation Oncology, Faculty of Medicine and University Hospital Carl Gustav Carus, Technische Universität Dresden, Dresden, Germany

11 OncoRay-National Center for Radiation Research in Oncology, Faculty of Medicine and University Hospital Carl Gustav Carus, Technische Universität Dresden, Helmholtz-Zentrum DresdenRossendorf, Dresden, Germany

12 German Cancer Consortium (DKTK), Partner Site Munich, Munich, Germany

13 Department of Radiation Oncology, Technical University of Munich (TUM), Klinikum rechts der Isar, Munich, Germany

14 Department of Radiation Sciences (DRS), Institute of Radiation Medicine (IRM), Neuherberg, Germany

15 Department of Nuclear Medicine, Hannover Medical School, Hannover, Germany

16 Department of Nuclear Medicine, Technical University of Munich (TUM), Klinikum rechts der Isar, Munich, Germany
17 Department of Nuclear Medicine, University of Duisburg-Essen and German Cancer Consortium (DKTK)-University Hospital Essen, Essen, Germany

18 Department of Nuclear Medicine, Charité-Universitätsmedizin Berlin, Freie Universität Berlin, Humboldt-Universität zu Berlin, Berlin Institute of Health, Berlin, Germany

19 German Cancer Consortium (DKTK), Partner Site Tübingen, and German Cancer Research Center (DKFZ), Heidelberg, Germany

20 Department of Radiation Oncology, University of Tübingen, Tübingen, Germany

21 Department of Radiotherapy and Special Oncology, Medical School Hannover, Hannover, Germany

22 Department of Nuclear Medicine, University Hospital Mainz, Mainz, Germany

23 Department of Nuclear Medicine, Faculty of Medicine, Medical Center, University of Freiburg, Freiburg, Germany

24 Department of Radiation Oncology, West German Cancer Centre, University of Duisburg-Essen, Essen, Germany

25 German Cancer Consortium (DKTK), Partner Site Frankfurt, and German Cancer Research Center (DKFZ), Heidelberg, Germany

26 Department of Radiotherapy and Oncology, Goethe-University Frankfurt, Frankfurt, Germany

27 Department of Nuclear Medicine, Rostock University Medical Centre, Rostock, Germany

28 Department of Radiation Oncology, Ulm University Hospital, Ulm, Germany

29 National Center for Tumor Diseases (NCT), Partner Site Dresden, Germany: German Cancer Research Center (DKFZ), Heidelberg, Germany, Faculty of Medicine and University Hospital Carl Gustav Carus, Technische Universität Dresden, Dresden, Germany, Helmholtz Association/Helmholtz-Zentrum DresdenRossendorf (HZDR), Dresden, Germany

30 German Cancer Consortium (DKTK), Partner Site Dresden, and German Cancer Research Center (DKFZ), Heidelberg, Germany

31 Department of Nuclear Medicine, Faculty of Medicine and University Hospital Carl Gustav Carus, Technische Universität Dresden, Dresden, Germany

32 Department of Nuclear Medicine, Klinikum Chemnitz gGmbH, Chemnitz, Germany 
33 Department of Radiation Oncology, Charité-Universitätsmedizin Berlin, Charité-Universitätsmedizin Berlin, Freie Universität Berlin, Humboldt-Universität zu Berlin, Berlin Institute of Health, Berlin, Germany

34 Section for Biomedical Physics, Department of Radiation Oncology, University of Tübingen, Tübingen, Germany

35 Helmholtz-Zentrum Dresden-Rossendorf, Institute of Radiooncology_OncoRay, Dresden, Germany 